\title{
Temporal evolution of a post-caldera, mildly peralkaline magmatic system: Furnas volcano, São Miguel, Azores
}

\author{
A. J. Jeffery ${ }^{1} \cdot$ R. Gertisser ${ }^{1} \cdot$ B. O'Driscoll ${ }^{2} \cdot$ J. M. Pacheco $^{3} \cdot$ S. Whitley ${ }^{1}$ ' \\ A. Pimentel ${ }^{3,4} \cdot$ S. Self ${ }^{5}$
}

Received: 1 October 2015 / Accepted: 22 January 2016 / Published online: 19 April 2016

(C) The Author(s) 2016. This article is published with open access at Springerlink.com

\begin{abstract}
Furnas is one of three active central volcanoes on São Miguel Island, Azores, and is considered to be one of the most hazardous in the archipelago. In this study, the pre-eruptive magma plumbing system of the 10 young $(<5 \mathrm{ka})$, intra-caldera, sub-Plinian, trachytic eruptions of the Upper Furnas Group (UFG) is investigated via whole rock major and trace element geochemistry, mineral chemistry, thermobarometry, and petrogenetic modelling. The main aim of this work is to elucidate the petrogenesis of the Furnas trachytes, constrain the P-T$\mathrm{fO}_{2}$ conditions under which they evolve, and investigate the temporal evolution of the magma plumbing system. Results indicate that the trachytes are derived predominantly from extended fractional crystallisation of alkali basalt parental magmas, at depths between $\sim 3$ and $4 \mathrm{~km}$.
\end{abstract}

Communicated by Jochen Hoefs.

Electronic supplementary material The online version of this article (doi:10.1007/s00410-016-1235-y) contains supplementary material, which is available to authorized users.

\section{A. J. Jeffery}

a.j.jeffery@keele.ac.uk

1 School of Physical and Geographical Sciences, Keele University, Keele, Staffordshire ST5 5BG, UK

2 School of Earth, Atmospheric, and Environmental Sciences, The University of Manchester, Manchester M13 9PL, UK

3 Centro de Vulcanologia e Avaliação de Riscos Geológicos, University of the Azores, 9501-801 Ponta Delgada, Azores, Portugal

4 Centro de Informação e Vigilância Sismovulcânica dos Açores, 9501-801 Ponta Delgada, Azores, Portugal

5 Department of Earth and Planetary Science, University of California, Berkeley, CA 94720, USA
This is considered to take place in a density-stratified reservoir, with alkali basalt magmas at the base and hydrous trachytes forming an upper cap or cupola. The presence of this reservoir at shallow crustal depths beneath the caldera likely inhibits the ascent and subsequent eruption of mafic magmas, generating a compositional Daly Gap. Rare syenitic ejecta represent in situ crystallisation of trachytic magmas in the thermal boundary zone at the top of the reservoir. Trachytic enclaves within these syenites, in addition to banded pumices and ubiquitous clinopyroxene antecrysts in the UFG pumice falls, provide evidence for mingling/mixing processes within the magmatic system. Despite relatively uniform major element compositions, systematic trace element variations within individual eruptions highlight the importance of fractional crystallisation during late-stage evolution of the trachytes. This is facilitated by the accumulation of water and the development of mild peralkalinity, which contribute to low pre-eruptive melt viscosities and efficient crystal settling. Compositional zoning patterns between individual eruptions cannot be accounted for by periodic tapping of a single magma batch undergoing fractional crystallisation. Instead, up to four individual cycles are recognised, in which a zoned cap of eruptible trachytic magma, formed at the top of the reservoir, was erupted in one or more eruptions and was re-established via intermittent replenishment and subsequent fractional crystallisation.

Keywords Furnas volcano - Peralkaline trachyte . Fractional crystallisation - Zoned magma reservoir . Post-caldera volcanism 


\section{Introduction}

Whilst peralkaline volcanic rocks are volumetrically less significant than their subalkaline counterparts, the petrogenetic processes that lead to their formation may be more complex (e.g. Mahood 1984; Mungall and Martin 1995; Scaillet and Macdonald 2001; White et al. 2009; Markl et al. 2010). Recent studies of peralkaline silicic magmatic systems have led to the general consensus that mafic magmas either act as a parental magma, linked to the peralkaline silicic magmas primarily by fractional crystallisation (e.g. Barberi et al. 1975; Self and Gunn 1976; Civetta et al. 1998; Peccerillo et al. 2007; Macdonald 2012), or alternatively act as a heat source generating crustal-derived partial melts which may then differentiate via fractional crystallisation (e.g. Bohrson and Reid 1997; Trua et al. 1999; Avanzinelli et al. 2004). Both of these models can be affected by varying degrees of crustal assimilation and magma mixing (Macdonald et al. 2015).

Here, we investigate the petrogenetic processes that operate in the basalt-trachyte suite of Furnas volcano, São Miguel, Azores (Fig. 1). Furnas volcano is an example of an oceanic island volcanic centre that exhibits many of the petrogenetic problems associated with peralkaline magmatic systems, including a volumetric abundance of felsic products with a peralkaline affinity, an apparent Daly Gap, and a spatial concentration of felsic products within the volcano's caldera complex, with mafic products on the flanks (Booth et al. 1978; Moore 1991). Guest et al. (1999) suggested that, similar to neighbouring volcanoes Sete Cidades and Fogo (Água de Pau), the felsic magmas of Furnas were largely generated via fractional crystallisation (cf. Storey et al. 1989; Moore 1991; Widom et al. 1992) and that the observed geographical distribution of mafic and felsic eruption products could result from the presence of established trachytic magma reservoirs that intercept ascending mafic magmas (cf. Wolff 1987). However, the evolution of peralkaline trachyte has not been quantitatively demonstrated at Furnas, and constraints upon the plumbing system are currently limited to geophysical studies (e.g. Machado 1972; Camacho et al. 1997; Montesinos et al. 1999), which broadly point towards a magma reservoir at shallow depths in the crust $(\sim 5 \mathrm{~km})$.

In this contribution, detailed petrography, mineral chemistry, thermobarometry, whole rock major and trace element geochemistry, as well as petrogenetic modelling, are applied to nine of the ten recent $(<5 \mathrm{ka})$ post-caldera eruptions that together constitute the Upper Furnas Group (UFG). With this data set, this study aims to: (1) investigate the petrogenesis and differentiation of mildly peralkaline silicic magmas at Furnas volcano and the generation of a Daly Gap, (2) place constraints upon the $\mathrm{P}-\mathrm{T}-\mathrm{fO}_{2}$ conditions of the magma

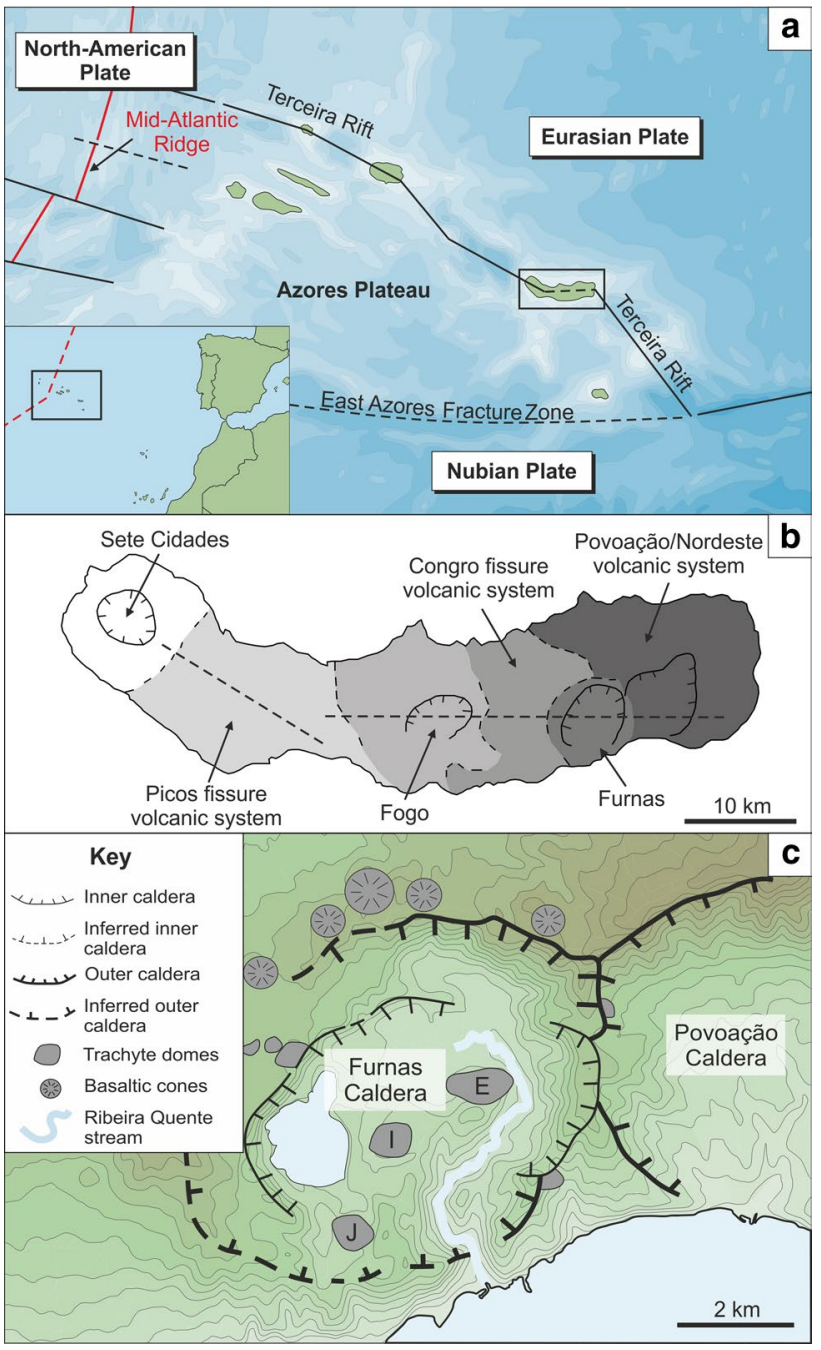

Fig. 1 Location maps of Furnas volcano, a summary map of the major tectonic features associated with the Azores triple junction, constructed after Searle (1980), Freire Luis et al. (1994), and Vogt and Jung (2004), b schematic map of São Miguel, highlighting the three active central volcanoes and fissure volcanic systems (adapted from Moore 1990), c summary map of the caldera complex of Furnas volcano and the neighbouring Povoação caldera. The lava domes associated with the Furnas E, I, and J eruptions are labelled. Modified after Guest et al. (1999) and Cole et al. (1999)

plumbing system beneath Furnas, and (3) evaluate the compositional evolution of a periodically tapped, metaluminous to mildly peralkaline magma plumbing system over a period of $\sim 5000$ years (Guest et al. 1999). A greater understanding of the pre-eruptive plumbing system of Furnas has implications for the processes that generate mildly peralkaline silicic magmas in such settings (e.g. Macdonald 2012), and the reestablishment and temporal evolution of post-caldera magmatic systems (e.g. Bachmann et al. 2012), as well as for the ongoing risk management of this highly active and hazardous volcano (e.g. Jones et al. 1999; Chester et al. 2002). 


\section{Geological background}

The Azores archipelago is located in the central North Atlantic Ocean (lat. $37^{\circ} \mathrm{N}$ to $40^{\circ} \mathrm{N}$, long. $25^{\circ} \mathrm{W}$ to $32^{\circ} \mathrm{W}$ ), $1300 \mathrm{~km}$ west of the Portuguese mainland. The islands are situated in a unique geodynamic setting as a result of the triple junction where the North American, Eurasian, and Nubian plates meet (Fig. 1a). The nine islands themselves are the emergent portions of large volcanic centres that rise from the Azores Plateau, a bathymetric and gravitational anomaly associated with a morphologically complex area $\left(\sim 5.8 \times 10^{6} \mathrm{~km}^{2}\right)$ of thickened oceanic crust that formed between 20 and 7 Ma (Kaula 1970; Ridley et al. 1974; Gente et al. 2003). The islands are divided into three groups based upon their geographical position. The central (Pico, Faial, São Jorge, Graciosa, Terceira) and eastern (Santa Maria and São Miguel) groups lie within a broadly triangular portion of the Azores Plateau, defined by three major tectonic features; the Mid-Atlantic Ridge in the west, the East Azores Fracture Zone (EAFZ) to the south, and the Terceira Rift to the north-east (Krause and Watkins 1970; Ridley et al. 1974; Vogt and Jung 2004; Luis and Miranda 2008). In contrast, the western group (Flores and Corvo) lie outside of this feature, on the western side of the MidAtlantic Ridge.

The island of São Miguel belongs to the eastern group and is the largest of the Azorean islands, comprising three active Quaternary trachytic central volcanoes [from west to east: Sete Cidades, Fogo (or Água de Pau), and Furnas] (Fig. 1b). Sete Cidades and Fogo are separated by the Picos basaltic fissure system (the Waist zone of Booth et al. 1978), whilst Furnas is separated from Fogo by the Congro basaltic fissure system (the Achada das Furnas complex of Booth et al. 1978). The easternmost part of the island is composed by the Pliocene-Pleistocene Povoação/Nordeste volcanic system, which is considered extinct (Fig. 1b). Unlike Sete Cidades and Fogo, Furnas lacks a distinctive constructive morphology and is instead made up of an approximately $7 \times 6 \mathrm{~km}$ nested caldera complex (Fig. 1c) that is considered to have been formed by at least two caldera-forming eruptions dated at $\sim 30,000{ }^{14} \mathrm{C}$ y B.P. and $\sim 12,000{ }^{14} \mathrm{C}$ y B.P. (Duncan et al. 1999; Guest et al. 1999; cf. Sibrant et al. 2015).

\section{Furnas eruptive history}

Furnas is considered to be one of the most active and hazardous volcanoes in the entire Azores archipelago, having erupted at least ten times in the last 5000 years. During its subaerial existence, Furnas has exhibited effusive (domeforming) to highly explosive (caldera-forming) eruptions of felsic magmas (Cole et al. 1999; Guest et al. 1999, 2015). Approximately 1500 people inhabit Furnas caldera, with several hundreds more in the immediate vicinity. A stratigraphical study by Guest et al. (1999) revealed that more than $90 \%$ of eruption products relating to Furnas are of pyroclastic nature, suggesting a volcanic history in which explosive activity is prevalent, certainly more so than the neighbouring Povoação/Nordeste volcanic system. Volcanism within the caldera complex has been exclusively trachytic in composition, with mafic products being limited to vents on the volcano's flanks. Although Guest et al. (1999) recognised a compositionally continuous sequence from basalt to trachyte, intermediate compositions were found to be subordinate in volume, indicating the presence of a compositional Daly Gap. The same study divided the stratigraphy of Furnas into three groups: the Upper (UFG), Middle (MFG), and Lower (LFG) Furnas groups. The LFG and MFG comprise numerous trachytic pyroclastic units, with minor trachytic domes and basaltic cones (Moore 1990). The boundary between the two groups is marked by the Povoação Ignimbrite Formation $\left(\sim 30,000{ }^{14} \mathrm{C}\right.$ y B.P.), a voluminous, partially welded, metaluminous to mildly peralkaline ignimbrite that fills much of the neighbouring Povoação caldera and is believed to represent the first caldera-forming eruption of Furnas volcano (Schmincke and Weibel 1972; Booth et al. 1978; Duncan et al. 1999).

The UFG is made up of at least ten intra-caldera, subPlinian eruptions of trachytic pumice, named Furnas A to $\mathrm{J}$ (the latter is also known as Furnas AD 1630; Cole et al. 1995; Guest et al. 2015) in order of decreasing age (Booth et al. 1978) (Online Resource 1). Of these eruptions, the latter two are known to have been historic, occurring after settlement on the island. Three of these eruptions are known to have also produced lava domes in their final stages (Furnas E, I, and J) (Cole et al. 1999). The dominant lithologies of the UFG are inter-bedded pumice lapilli and ash beds that are inferred to be the result of complex transitions between magmatic and phreatomagmatic activity during eruption, though Furnas $\mathrm{H}$ appears to have comprised exclusively magmatic activity (see stratigraphic logs in Online Resource 2) (Cole et al. 1995; Guest et al. 1999). The base of the UFG is marked by a deposit from nearby Fogo volcano, named Fogo A (Walker and Croasdale 1971). Radiocarbon ages for Fogo A range from 4480 to $5380{ }^{14} \mathrm{C}$ y B.P. (e.g. Moore and Rubin 1991; Wallenstein 1999; Pensa et al. 2015), but its age is generally reported as $\sim 5 \mathrm{ka}$. Although the deposit is not genetically related to Furnas, it is well known and easily identified and, in the absence of well-exposed deposits relating to the second caldera-forming event at Furnas $\left(\sim 12,000{ }^{14} \mathrm{C}\right.$ y B.P.), was chosen as the reference stratigraphic marker of the island that delimits the base of the UFG (Guest et al. 1999). Other 
deposits from Fogo are also commonly included within the stratigraphical sequence of the UFG to act as chronological reference points (e.g. Cole et al. 1999).

\section{Petrography}

\section{Pumice falls}

The fall deposits of the UFG are dominated by highly vesicular $(\sim 85 \%)$, aphyric to crystal poor $(<5 \%$ phenocryst content) pumice clasts. The dominant mineralogy shows little variation throughout the deposits, comprising alkali feldspar ( 67 vol\%), Fe-Ti oxides ( 20 vol\%), biotite ( 10 vol\%), clinopyroxene ( 3 vol\%), and apatite (accessory). Rarely, alkali feldspar microlites with high aspect ratios are observed. Additionally, a small number of pumice clasts from layer Lf of Furnas $\mathrm{J}$ (see Cole et al. 1995) exhibit pronounced banding, notably higher crystal contents, more abundant groundmass microlites, and rare inclusions of dense, crystalline material of similar mineralogy to the pumice, which range in size from $\sim 0.5$ to $6 \mathrm{~mm}$.

Alkali feldspar is the most abundant phase and exists as phenocrysts (up to $\sim 2 \mathrm{~mm}$ ), microphenocrystic fragments, and, more rarely, groundmass microlites. Phenocrysts are commonly tabular and euhedral (Fig. 2a), but rare examples are rounded, with pronounced embayment structures and resorbed cores (Fig. 2b). Small crystal fragments with irregular, fractured forms are also present, which may be heavily resorbed. Such examples are particularly common in the banded pumices of Furnas J, described above. Where groundmass microlites are present, they are almost exclusively acicular and do not exceed $100 \mu \mathrm{m}$ in length.

Clinopyroxene exists as microphenocrysts, typically $<0.5 \mathrm{~mm}$ in length (Fig. 2c). Inclusions of acicular apatite are frequently observed, and $\mathrm{Fe}-\mathrm{Ti}$ oxide inclusions are ubiquitous. More rarely, small $(<50 \mu \mathrm{m})$ clinopyroxene crystals are seen with irregular crystal forms, either heavily fractured, or rounded and resorbed. Such examples are more abundant in the banded pumices of Furnas J.

Biotite occurs as small $(<0.5 \mathrm{~mm})$ microphenocrysts (Fig. 2d). Crystal forms are dominantly euhedral to subhedral and may show evidence for resorption. Fe-Ti oxides are generally very small $(<0.5 \mathrm{~mm})$, subhedral, and frequently associated with clinopyroxenes. More rarely, they may be found as inclusions within feldspars. They are ubiquitously associated with small, acicular apatite crystals, which may be partially or fully included within the Fe-Ti oxide host.

\section{Lava domes}

Samples collected from the two lava domes associated with Furnas I and J reveal mineral assemblages that are broadly similar to those of the UFG pumice falls, including phenocrysts and microphenocrysts of alkali feldspar, clinopyroxene, $\mathrm{Fe}-\mathrm{Ti}$ oxides, biotite, and apatite, in approximate order of decreasing abundance. However, due to several key mineralogical and textural differences, the two domes are treated separately.

The lava dome associated with Furnas $\mathbf{J}$ is dominated by alkali feldspar, which can be found as phenocrysts up to $\sim 5 \mathrm{~mm}$ in size, and also as relatively coarse, acicular microlites in the groundmass (up to $\sim 0.4 \mathrm{~mm}$ ). Phenocrystic feldspars range from euhedral to subhedral, with rounded edges and uncommon embayments providing evidence for partial resorption. Feldspar microlites are frequently aligned, giving the groundmass a well-defined trachytic texture, which is also taken up by proximal phenocrysts. Rarely, feldspars are observed as glomerocrysts that reach sizes of up to $\sim 2 \mathrm{~mm}$ and comprise a number of partially resorbed feldspar phenocrysts that meet at irregular and often lobate boundaries (Fig. 2e).

Clinopyroxene is found throughout the dome as phenocrysts (up to $\sim 1 \mathrm{~mm}$ ) and groundmass microlites (up to $\sim 0.1 \mathrm{~mm}$ ). As observed in the UFG pumice falls, it is characteristically green in thin section and ubiquitously associated with smaller Fe-Ti oxide crystals which are partially or totally included within the larger clinopyroxene crystal.

Phenocrystic and microphenocrystic clinopyroxenes display brown alteration rims that also extend along any fractures that cut through the crystal (Fig. 2f). In addition to $\mathrm{Fe}-\mathrm{Ti}$ oxides, small apatite needles are also frequently observed as inclusions.

$\mathrm{Fe}-\mathrm{Ti}$ oxides are found as uncommon microphenocrysts (generally between 0.25 and $0.5 \mathrm{~mm}$ in size) and abundant groundmass crystals $(<50 \mu \mathrm{m})$. Microphenocrysts frequently exhibit exsolution lamellae of ilmenite. Such features are rare in the groundmass oxides. Like the UFG pumice falls, inclusions and partial inclusions of apatite are abundant.

Biotite is uncommon and is generally found as microphenocrysts, $<0.2 \mathrm{~mm}$ in length. Examples are frequently well formed and often aligned with the trachytic texture in the groundmass. Rare examples of larger, phenocrystic biotite, up to $0.75 \mathrm{~mm}$ in length, are present in some samples. Unlike microphenocrystic biotite, these examples are ragged and exhibit prominent reaction rims (Fig. $2 \mathrm{~g}$ ), which contain abundant small Fe-Ti oxides, and also run along some fractures and cleavage planes.

In contrast to the UFG pumice falls, the Furnas J dome also contains sodalite, which can be found as well-formed, equant microphenocrysts that are typically $0.2 \mathrm{~mm}$ in size. Inclusions of feldspar and clinopyroxene are extremely common, and feldspar microlites frequently impinge upon the sodalite crystal faces. In some cases, sodalite appears rounded and partially embayed, indicating resorption. 
Fig. 2 Representative photomicrographs for the UFG, a euhedral alkali feldspar phenocryst in vesicular glass (xpl), b highly resorbed and embayed alkali feldspar phenocryst (xpl), c clinopyroxene phenocryst with numerous $\mathrm{Fe}-\mathrm{Ti}$ oxide and apatite inclusions (ppl), d subhedral biotite phenocryst in highly vesicular glass (ppl), e alkali feldspar glomerocryst with irregular internal boundaries, surrounded by a mediumgrained, trachytic groundmass (Furnas I lava dome) (xpl), f clinopyroxene phenocryst with distinctive oxidation rim and numerous $\mathrm{Fe}-\mathrm{Ti}$ oxide inclusions (Furnas $\mathbf{J}$ lava dome) (ppl), g large, reacted biotite phenocryst remnant (Furnas I lava dome) (ppl), h Na-Ca amphibole, aegirine-augite, and sodalite groundmass crystals, surrounded by alkali feldspar laths in the Furnas I lava dome (ppl). Fsp alkali feldspar, $C p x$ clinopyroxene, $B t$ biotite, Amp amphibole, $S d l$ sodalite. Sample numbers given in upper right of each image
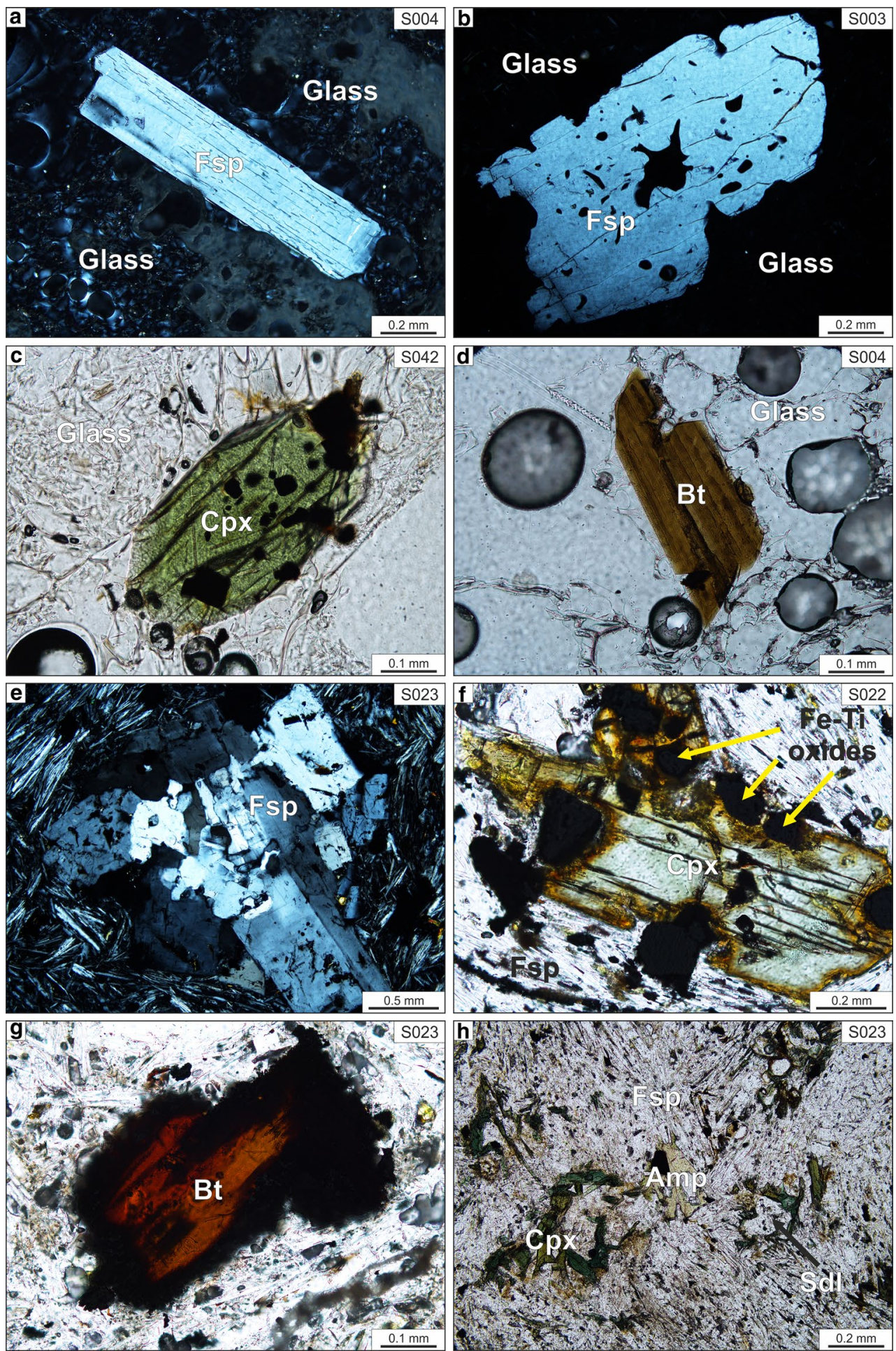

The Furnas I lava dome rock is similar to that from the Furnas J dome, containing alkali feldspar phenocrysts surrounded by a coarse, alkali feldspar-based groundmass, as well as uncommon alkali feldspar glomerocrysts that show irregular and lobate interior grain boundaries. Clinopyroxene is found as anhedral phenocrysts (up to $\sim 1 \mathrm{~mm}$ ) in length and as small microlites in the groundmass. Fe-Ti oxides are present as frequently exsolved microphenocrysts that are associated with the clinopyroxene phenocrysts, and as groundmass crystals. Biotite is observed in the Furnas I dome, as small subhedral microphenocrysts $(<0.2 \mathrm{~mm})$, or rare, ragged phenocrysts with an $\mathrm{Fe}-\mathrm{Ti}$ oxide-rich reaction rim. Sodalite microphenocrysts are generally small $(<0.2 \mathrm{~mm})$ and euhedral, with abundant inclusions of 
feldspar and clinopyroxene (Fig. 2h). The Furnas I dome also contains amphibole, found only as anhedral, interstitial crystals in the groundmass (Fig. 2h).

\section{Syenite nodules}

A small number of coarse-to-medium-grained syenitic clasts ejected as cognate xenoliths were sampled from the pyroclastic surge units associated with the Furnas $\mathbf{J}$ eruption. Individual specimens rarely exceed $\sim 10 \mathrm{~cm}$ in size, and, in some instances, contain enclaves of darker, finer-grained rock. Boundaries between enclave material and host syenite range from sharp and well defined to irregular and diffuse, and, in some samples, both boundary types can be observed. Syenite mineral assemblages are dominated by cumulus alkali feldspar, which reaches sizes of up to $5 \mathrm{~mm}$, and frequently displays perthitic textures. Intercumulus phases include clinopyroxene, amphibole, Ti-magnetite, ilmenite, biotite, pyrrhotite, and rare zircon (Online Resource 3). Miarolitic cavities are common in both the syenites and enclaves. Unlike reported syenitic ejecta from Terceira (Jeffery et al. 2016), Ascension (e.g. Harris 1983), and nearby Fogo volcano (Ridolfi et al. 2003), the Furnas syenites do not contain any of the $\mathrm{Na}-\mathrm{K}-\mathrm{Ca}-\mathrm{Ti}-\mathrm{Zr}$ silicate minerals that characterise agpaitic phase assemblages (e.g. aenigmatite, astrophyllite, eudialyte, cf. Marks et al. 2011). Instead, Ti-magnetite, ilmenite, and trace amounts of zircon indicate that the syenites are miaskitic.

\section{Methods}

\section{Analytical techniques}

\section{Whole rock analyses}

Whole rock major and trace element analyses for the UFG were undertaken at The Open University, UK, using an Applied Research Laboratories $8420+$ dual goniometer wavelength-dispersive $\mathrm{X}$-ray fluorescence (XRF) spectrometer. Additional analyses were produced using a Bruker AXS S4 Pioneer XRF spectrometer at the University of East Anglia, UK. The trace element concentrations of a small subset of samples were determined via inductively coupled plasma mass spectrometry (ICP-MS), using an Agilent $7500 \mathrm{~s}$ quadrupole mass spectrometer at The Open University, UK. Additional major and trace element analyses were undertaken at Bureau Veritas Mineral Laboratories, Canada, using inductively coupled plasma atomic emission spectroscopy (ICP-AES) for major element analysis and ICP-MS for trace element analysis.
The whole rock data set was supplemented by 117 quantitative analyses from various stratigraphic levels within the UFG, focussing on selected trace elements $(\mathrm{Zr}$, $\mathrm{Nb}, \mathrm{Rb}, \mathrm{Sr}$ ). This was achieved by $\mathrm{X}$-ray fluorescence (XRF) at Keele University, UK, using a Niton X13t energydispersive XRF spectrometer. Further details of analytical procedures and data quality are provided in Online Resources 4 and 5.

\section{Mineral and glass analyses}

Major element compositions of mineral phases and glass (both melt inclusions and groundmass glass) were analysed using a CAMECA SX 100 electron microprobe at The Open University, UK, and a JEOL JXA 8900 RL electron microprobe at the University of Göttingen, Germany. Full details of the analytical procedure and data quality are given in Online Resources 4 and 5.

\section{Thermobarometry}

In the presence of both Ti-magnetite and ilmenite, magmatic temperatures and oxygen fugacity $\left(\mathrm{fO}_{2}\right)$ estimates were calculated using the ILMAT program of Lepage (2003), applying the model of Andersen et al. (1993) with the calculation scheme of Stormer (1983) to determine values for $X_{\mathrm{hem}}, X_{\mathrm{ilm}}, X_{\mathrm{mag}}, X_{\mathrm{ulv}}$. The application of alternative calculation schemes (e.g. Carmichael 1967; Anderson 1968; Lindsley and Spencer 1982) led to variation of no more than $5 \%$ in the calculated results. Equilibrium between mineral pairs was evaluated using the Mn-Mg partitioning test of Bacon and Hirschmann (1988). Pre-eruptive magmatic temperatures were also estimated using the alkali feldspar-melt thermometer of Putirka (2008). In addition to pre-eruptive temperatures, magmatic $\mathrm{H}_{2} \mathrm{O}$ contents were also estimated, using the hygrometer of Mollo et al. (2015). Due to the absence of notable chemical zonation within $\mathrm{Fe}-\mathrm{Ti}$ oxide and alkali feldspar crystals, both core and rim analyses were used in the calculations, which were based upon individual mineral (and glass) analyses rather than averages. Full details of the applied procedure are provided in Online Resource 4.

\section{Geochemical modelling}

To investigate the petrogenesis of the UFG trachytes, a variety of approaches were applied, including Rayleigh fractionation and batch melting trace element modelling, least squares mass balance modelling, and thermodynamic modelling. The full details of the applied models are given in Online Resource 4. 


\section{Results}

\section{Major and trace element geochemistry}

Whole rock major element data for the UFG units are reported in Online Resource 6. Notably, analyses for Furnas $\mathrm{A}$ and $\mathrm{B}$ have lower $\mathrm{SiO}_{2}$ and $\mathrm{Na}_{2} \mathrm{O}$ values, in addition to elevated LOI values, which are indicative of post-depositional alteration, and lead to misleadingly low calculated peralkalinity indices. For this reason, neither analysis is considered in the following discussion.

The UFG whole rock samples exhibit little major element variation, with $\mathrm{SiO}_{2}$ values that cluster around $63 \mathrm{wt} \%$, low $\mathrm{MgO}$ contents $(<0.5 \mathrm{wt} \%)$, and high total alkali abundances $(\sim 13 \mathrm{wt} \%)$. Using the total alkali versus silica diagram of Le Bas et al. (1986), the UFG samples plot uniformly within the trachyte field (Fig. 3). The UFG pumice falls are mildly peralkaline, with peralkalinity indices (P.I.) that range from 1.02 to 1.13 . The UFG lava domes range from metaluminous to mildly peralkaline, with a P.I. range of $0.95-1.05$. All of the samples are silica undersaturated, with a range in normative nepheline of 0.15$6.10 \mathrm{wt} \%$, correlating positively with P.I.. Due to the crystal poor nature of the UFG pumice falls, groundmass glass analyses are very similar in composition to whole rock and can be classified as trachyte (Fig. 3).

Trace element analyses for the UFG are presented in Online Resource 6. Chondrite-normalised REE patterns shown in Fig. 4a, and compared with a standard OIB (Sun and McDonough 1989), reveal a relatively uniform enrichment in LREEs relative to HREEs, with $\mathrm{La}_{\mathrm{N}} / \mathrm{Yb}_{\mathrm{N}}$ ratios between 11 and 27. They also display a pronounced, negative Eu anomaly, with $\mathrm{Eu} / \mathrm{Eu}^{*}$ values between 0.12 and 0.22 . This anomaly is somewhat smaller in the lava domes $(0.30$ 0.32 ), and in the first two eruptions of the UFG (Furnas A and $\mathrm{B}, 0.37$ and 0.45 , respectively), though the effects of post-depositional alteration cannot be ruled out in the latter.

Figure $4 \mathrm{~b}$ presents a multi-element diagram, showing UFG data and a standard OIB, normalised against the primitive mantle composition of Sun and McDonough (1989). Notable troughs occur for $\mathrm{Ba}, \mathrm{Sr}, \mathrm{Eu}, \mathrm{Ti}$, and, in some cases, $\mathrm{Pb}$. In particular, $\mathrm{Sr}$ and $\mathrm{Ba}$ reach concentrations which are lower than primitive mantle concentrations.

\section{Mineral chemistry}

All of the mineral chemical data discussed in the following section is provided in Online Resource 7.

\section{Feldspar}

The majority of UFG feldspar analyses lie at the anorthoclase-sanidine boundary, with compositions within $\mathrm{Or}_{23-48}$,

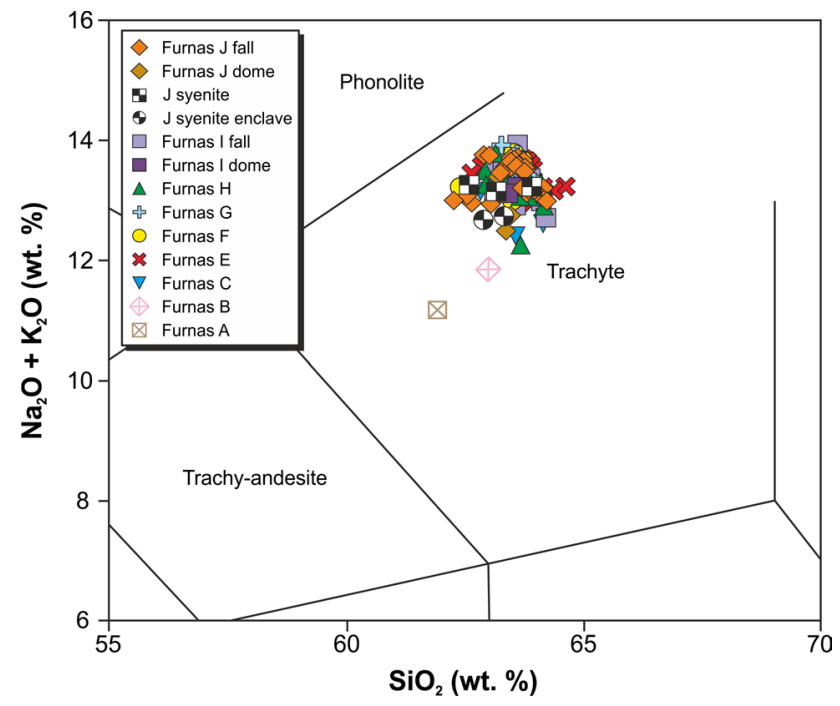

Fig. 3 UFG compositions plotted into the Total alkali-silica classification scheme of Le Bas et al. (1986). Whole rock analyses, groundmass glass and melt inclusions are plotted together and show uniform trachytic compositions

$\mathrm{Ab}_{48-69}, \mathrm{An}_{0-7}$ (Fig. 5a). Feldspar phenocryst analyses from the lava domes of Furnas $\mathrm{J}$ and Furnas I exhibit a similar range to their respective pumice falls, though they extend to slightly more sodic compositions. Substituting elements such as $\mathrm{Ba}, \mathrm{Sr}$, and $\mathrm{Fe}$ are frequently below the detection limit. Feldspars from the Furnas $\mathbf{J}$ syenites are similar in composition to those of the other UFG units, with a range of $\mathrm{Or}_{26-57}, \mathrm{Ab}_{43-72}, \mathrm{An}_{0-5}$, and no variation between syenite and enclave. Concentrations of $\mathrm{Ba}, \mathrm{Sr}$, and $\mathrm{Fe}$ are, like the UFG, frequently below detection limits.

\section{Clinopyroxene}

For classification, the ten component scheme of Marks et al. (2008) was applied. When plotted in the quadrilateral, three component (Wo-En-Fs) scheme of Morimoto et al. (1988) (Fig. 5b), UFG clinopyroxenes lie at the diopside-augite boundary. Analyses derived from clinopyroxene phenocrysts in the Furnas $\mathbf{J}$ and Furnas I lava domes do not show any significant compositional variation compared to their corresponding pumice falls. The analyses are best defined using $\mathrm{Di}, \mathrm{Hd}$, and Aeg, which exhibit ranges of $\mathrm{Di}_{45-70}, \mathrm{Hd}_{12-37}$, and $\mathrm{Aeg}_{2-18}$ (Fig. 5b). In Di-Hd-Aeg space, some Furnas samples exhibit a trend of enrichment in $\mathrm{Hd}$, with little to no increase in the aegirine component. Other units show more homogenous compositions (e.g. Furnas H), though some comparatively Di-rich outliers are present. The Furnas J lava dome has a larger compositional range than the Furnas J pumice fall, extending to more Di-rich compositions. Similarly, the Furnas I lava dome clinopyroxenes show a somewhat greater range than the Furnas I pumice fall, though this 
Fig. 4 Trace element variation diagrams for the UFG, a REE compositions of the UFG. All data are normalised relative to chondrite values and plotted against typical oceanic island basalt (OIB) compositions (Sun and McDonough 1989), b multi-element trace element variation diagram of the UFG. All data are normalised to primitive mantle values (Sun and McDonough 1989)
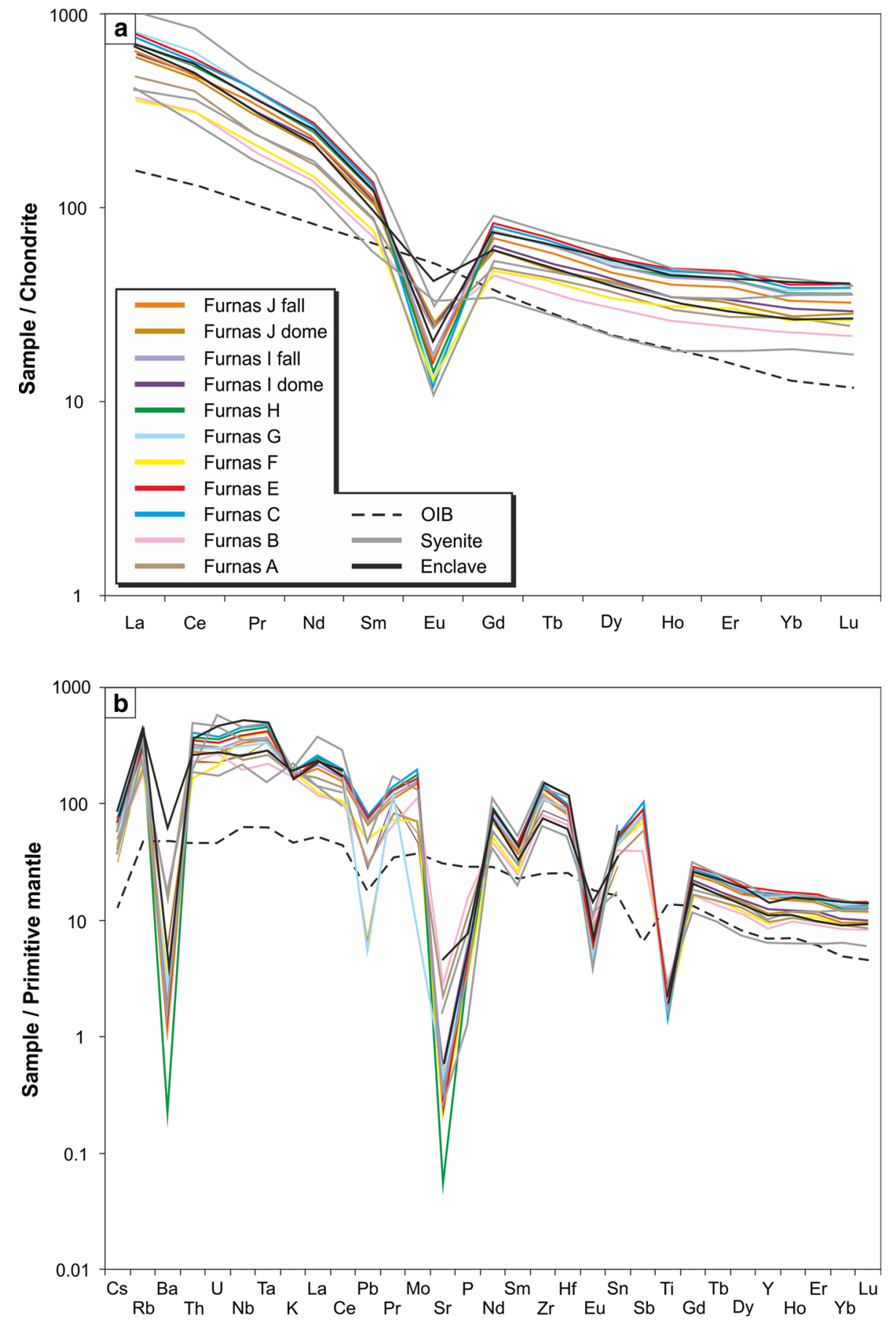

range extends to more Aeg-rich compositions. Two analysed groundmass crystals are outliers within this unit, with compositions of $\mathrm{Di}_{33}, \mathrm{Hd}_{37}, \mathrm{Aeg}_{26}$, and $\mathrm{Di}_{12}, \mathrm{Hd}_{7}, \mathrm{Aeg}_{58}$, and so may represent a continuation of the described trend, where Aeg enrichment begins after initial Hd enrichment.

The clinopyroxene analyses from the Furnas $\mathrm{J}$ syenite ejecta lie in stark contrast with the rest of the UFG units, with a compositional range from diopside, through aegirineaugite, to aegirine $\left(\mathrm{Qd}_{0-93}, \mathrm{Jd}_{0-8}, \mathrm{Aeg}_{6-96}\right)$. The Ti-aegirine component is generally present in small concentrations
( $\sim \mathrm{mol} \%$ ), but extends to values as high as $34 \mathrm{~mol} \%$ in a small number of analyses. In Di-Hed-Aeg space, the data reveal a poorly defined trend of initial enrichment in hedenbergite, followed by aegirine enrichment.

\section{$\mathrm{Fe}-\mathrm{Ti}$ oxides}

Quantitative analyses of both Ti-magnetite and ilmenite for the UFG are presented in the $\mathrm{TiO}_{2}-\mathrm{FeO}-\mathrm{Fe}_{2} \mathrm{O}_{3}$ ternary system in Fig. 5c. Analyses were stoichiometrically 
corrected for ferric iron. Ti-magnetite shows a compositional range of Magnetite ${ }_{35-68}$, Ulvöspinel ${ }_{22-63}$, Spinel $_{1-10}$, with an average $\mathrm{Al}_{2} \mathrm{O}_{3}$ content of $0.9 \mathrm{wt} \% . \mathrm{MgO}$ and $\mathrm{MnO}$ contents reach 1.3 and $2.7 \mathrm{wt} \%$, respectively. The available ilmenite analysis from the Furnas $\mathbf{J}$ dome has a relatively $\mathrm{MgO}$ and $\mathrm{MnO}$ rich composition (Ilmenite ${ }_{78}$, .yrophanite $_{9}$, Geikielite $_{13}$ ). Ti-magnetite from the Furnas J syentite ejecta is similar to that of other UFG lithologies, with a range of Magnetite $_{49-67}$, Ulvöspinel ${ }_{32-50}$, Spinel ${ }_{0-1}$, whereas ilmenite from the syenites is notably enriched in $\mathrm{MnO}$ and shows essentially no $\mathrm{MgO}$ (Ilmenite $_{53-75}$, Pyrophanite ${ }_{24-46}$, Geikielite $_{0-1}$ ).

\section{Biotite}

Biotite analyses from the UFG are Mg-rich, characterised by relatively constant $\mathrm{Fe} /(\mathrm{Fe}+\mathrm{Mg})$ ratios $(\sim 0.41)$, and variable $\mathrm{Si}$ contents [5.44-5.71 atoms per formula unit (apfu)] (Fig. 5d). UFG analyses also exhibit high Ti contents (0.56-0.93 apfu). Occupation of the two hydroxyl sites is characterised by variably high $F$ contents $(0.32-1.63 \mathrm{apfu})$ and low $\mathrm{Cl}$ contents $(<0.02 \mathrm{apfu})$. Biotite from the Furnas $\mathbf{J}$ syenite ejecta are very similar to those found in the pumice falls and lava domes, with variable $\mathrm{Si}$ contents (5.54-5.90 apfu), and high Ti (0.42-0.84 apfu). Similarly, the hydroxyl sites are dominated by $\mathrm{F}(0.75-1.12$ apfu), with little $\mathrm{Cl}$ $(<0.02 \mathrm{apfu})$. However, $\mathrm{Fe} /(\mathrm{Fe}+\mathrm{Mg})$ ratios extend to larger values $(0.44-0.72)$.

\section{Amphibole}

Following the nomenclature of Leake et al. (1997), all of the Furnas I dome analyses are $\mathrm{Na}-\mathrm{Ca}$ amphiboles of magnesio-katophoritic to richteritic composition (Fig. 5e, f). Chlorine concentrations are generally close to the detection limit $(<0.004 \mathrm{apfu})$. The role of $\mathrm{F}$ in the hydroxyl site was not quantified. Amphiboles in the Furnas $\mathrm{J}$ syenites exhibit a larger compositional range, which includes $\mathrm{Na}-$ $\mathrm{Ca}$ amphiboles of kataphoritic composition, and $\mathrm{Na}$ amphiboles of ferric-ferronyböitic and arfvedsonitic composition. Fluorine concentrations in the hydroxyl site range from 0.45 to $1.21 \mathrm{apfu}$ and show no significant variation between $\mathrm{Na}-\mathrm{Ca}$ and $\mathrm{Na}$ groups. Chlorine contents are extremely low $(<0.006 \mathrm{apfu})$.

\section{Discussion}

In this section, the combined data set is used to provide insights into the pre-eruptive magmatic system of the young $(<5 \mathrm{ka})$ volcanic activity of Furnas, exploring first the preeruptive $\mathrm{P}-\mathrm{T}-\mathrm{fO}_{2}$ conditions of the UFG trachytes, and the petrogenetic processes that generate them. Ultimately, this allows the construction of a conceptual model for the magma plumbing system. Second, the compositional zonation patterns observed throughout the UFG, both within and between individual eruptions, are used to place constraints upon the temporal evolution of the magma reservoir from which the UFG eruptions were fed.

\section{P-T- $-\mathrm{fO}_{2}$ constraints on the plumbing system}

\section{Thermobarometric models}

Due to the scarcity of ilmenite in the Furnas samples, temperature and $\mathrm{fO}_{2}$ estimates for the trachytes, based upon two-oxide equilibria, could only be achieved for the Furnas $\mathrm{J}$ lava dome and the syenite ejecta. Ti-magnetite analyses from the Furnas J pumice fall were also tested for equilibrium with Furnas $\mathrm{J}$ dome ilmenite, and a single additional pairing was found to be suitable for calculation. Estimates for the Furnas $\mathrm{J}$ lava dome indicate a temperature range of $\sim 80{ }^{\circ} \mathrm{C}$ between 814 and $897{ }^{\circ} \mathrm{C}$ and $\mathrm{fO}_{2}$ values that are slightly above the FMQ buffer (Fig. 6a). As the temperature decreases, the $\mathrm{fO}_{2}$ values increase slightly, reaching approximately $0.5 \log$ units above the FMQ curve at the lowest recorded temperatures. These values are representative of the final pre-eruptive magmatic temperatures and/or syn-eruptive conditions within the plumbing system, due to the rapid re-equilibration timescales of coexisting $\mathrm{Fe}-\mathrm{Ti}$ oxides (e.g. Gardner et al. 1995; Venezky and Rutherford 1999; Pimentel et al. 2015). The pre-eruptive redox conditions of the UFG trachytes appear to be more reducing than those of nearby Sete Cidades, where a total range of $\sim \mathrm{FMQ}+1$ to $\sim \mathrm{MH}-1$ was reported by Beier et al. (2006). Interestingly, in the case of Sete Cidades volcano, both the caldera-forming and the post-caldera deposits (the latter being comparable to the UFG) record significantly more oxidising conditions than the UFG. This substantial variation may be linked to degassing of $\mathrm{H}_{2}$ following the thermal disassociation of $\mathrm{H}_{2} \mathrm{O}$ (cf. Mungall and Martin 1995) and would indicate a greater degree of magma degassing in the post-caldera magma system of Sete Cidades compared to that of Furnas. Equilibrium testing for the syenites indicates only four equilibrium pairs, yielding temperatures between 621 and $780{ }^{\circ} \mathrm{C}$, and $\mathrm{fO}_{2}$ values that become more reduced at lower temperatures, ranging from 0.5 to 2 units below FMQ (Online Resource 8).

Pre-eruptive temperature estimates for the trachytes were also calculated via alkali feldspar-melt thermometry (Putirka 2008), using an initial estimated pressure input of $100 \mathrm{MPa}$. The effect of pressure is, in this case, negligible, with a change in calculated temperature of $<1{ }^{\circ} \mathrm{C}$ following a pressure increase of one order of magnitude. In each case, a range of up to 19 whole rock and groundmass glass compositions were used as potential equilibrium liquid 

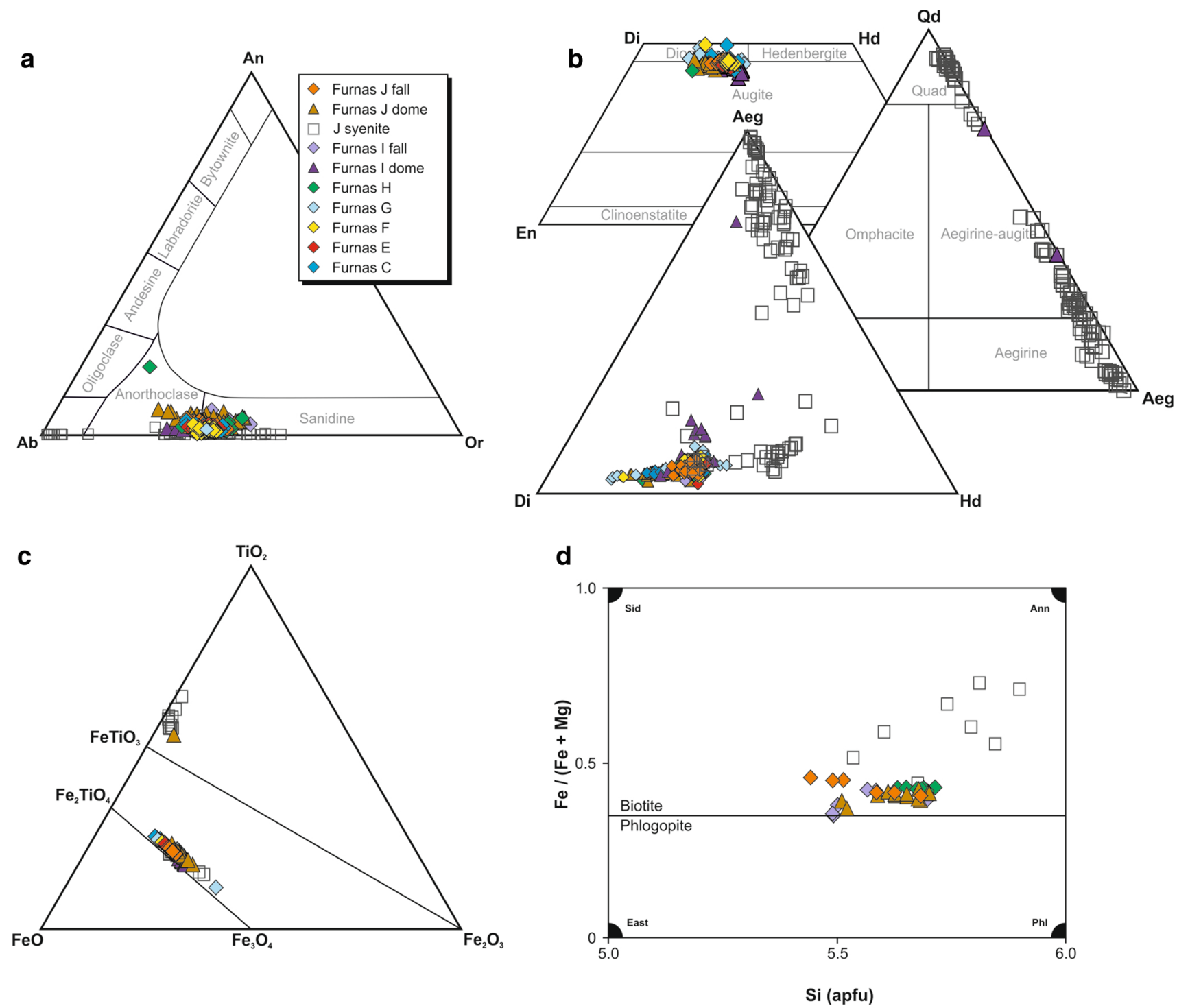

e
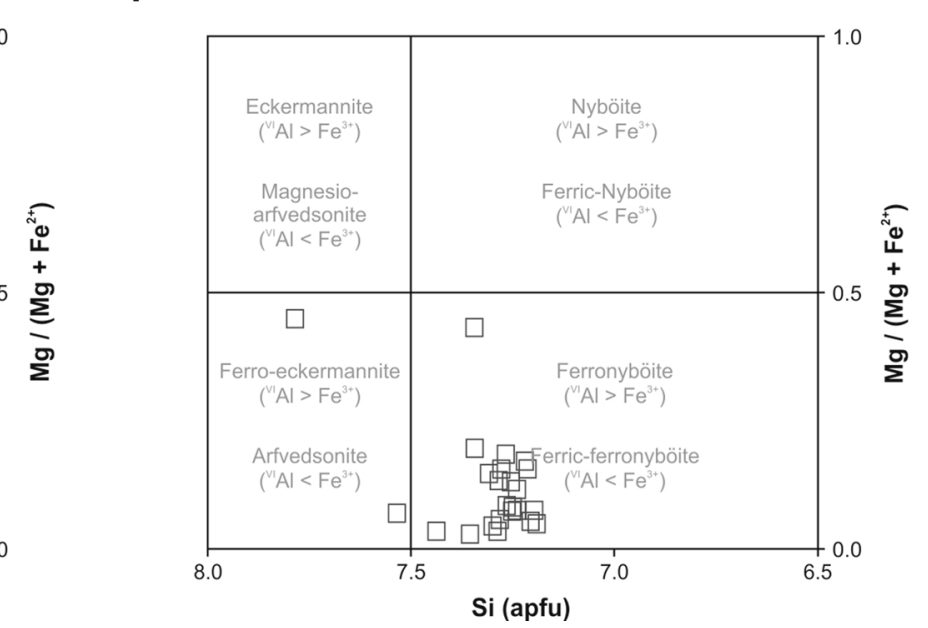
4Fig. 5 Mineral compositions of the UFG, a alkali feldspar compositions plotted into the ternary An-Ab-Or system, b clinopyroxene compositions plotted into the pyroxene quadrilateral and, where relevant, the ternary Qd-Jd-Aeg system (Morimoto et al. 1988) and the ternary $\mathrm{Di}-\mathrm{Hd}-\mathrm{Aeg}$ system, $\mathbf{c} \mathrm{Fe}-\mathrm{Ti}$ oxide compositions plotted into the $\mathrm{TiO}_{2}-\mathrm{FeO}-\mathrm{Fe}_{2} \mathrm{O}_{3}$ ternary system, $\mathbf{d}$ biotite compositions for the Furnas $\mathrm{H}$, I, and $\mathbf{J}$ pumice falls, and the Furnas $\mathrm{J}$ syenites, e $\mathrm{Na}-\mathrm{Ca}$ amphibole compositions for the Furnas I lava dome and the Furnas J syenites, plotted in the scheme of Leake et al. (1997), f Na-amphibole compositions for the Furnas J syenites, plotted in the scheme of Leake et al. (1997)

compositions and the most suitable was identified using the $\mathrm{KD}_{\mathrm{Or}-\mathrm{Ab}}$ equilibrium test presented by Mollo et al. (2015). In the majority of cases, all of the alkali feldspar analyses from a single eruption were found to be well equilibrated with a single groundmass glass or whole rock analysis from the same eruption. However, in the case of Furnas J, the most applicable equilibrium liquid for alkali feldspars from both the pumice fall and the lava dome was found to be a whole rock analysis of the lava dome (SM7-1) (Online Resource 8).

Calculated temperature estimates for the UFG are summarised in Fig. 6b. The UFG exhibits a temperature range of $855-965{ }^{\circ} \mathrm{C}$, with some fluctuation between individual eruptions. For example, the pumice fall and lava dome of Furnas $\mathrm{J}$ record temperatures in excess of $915{ }^{\circ} \mathrm{C}$, whilst the majority of earlier UFG eruptions yield somewhat lower temperatures that are generally below $900{ }^{\circ} \mathrm{C}$. Furnas $\mathrm{F}$ represents a notable exception to this, with a narrow range of hotter temperature estimates between 922 and $935{ }^{\circ} \mathrm{C}$. Estimates derived from syenite ejecta are similar to those of the UFG falls and domes, but with greater scatter, ranging from 892 to $969^{\circ} \mathrm{C}$. The limited available estimates for the enclaves yield temperatures that are not distinguishable from the host syenites. The comparatively wide range of temperature estimates observed in the syenites may reflect the temporal variation in feldspar nucleation that inevitably results from in situ crystallisation.

Estimates of pre-eruptive $\mathrm{H}_{2} \mathrm{O}$ contents $\left(\mathrm{H}_{2} \mathrm{O}_{\text {melt }}\right)$ of the trachytes were determined for each unit of the UFG via alkali feldspar-melt equilibria (Mollo et al. 2015). In each case, equilibrium liquid compositions were carried over from alkali feldspar-melt thermometry. Due to the dependency of calculated $\mathrm{H}_{2} \mathrm{O}_{\text {melt }}$ values upon the input temperature, the average temperature estimate derived from alkali feldspar-melt thermometry was used as an input for each of the UFG units. Calculated $\mathrm{H}_{2} \mathrm{O}_{\text {melt }}$ estimates for the UFG are summarised in Fig. 6b. Results indicate that the UFG was hydrous, with average $\mathrm{H}_{2} \mathrm{O}_{\text {melt }}$ values around $5 \mathrm{wt} \%$, and a total range from 2.4 to $6.1 \mathrm{wt} \%$. This range is consistent with the measured water contents of trachytic glass inclusions within alkali feldspars sampled from Furnas J (Jeffery 2016). The negative correlation between
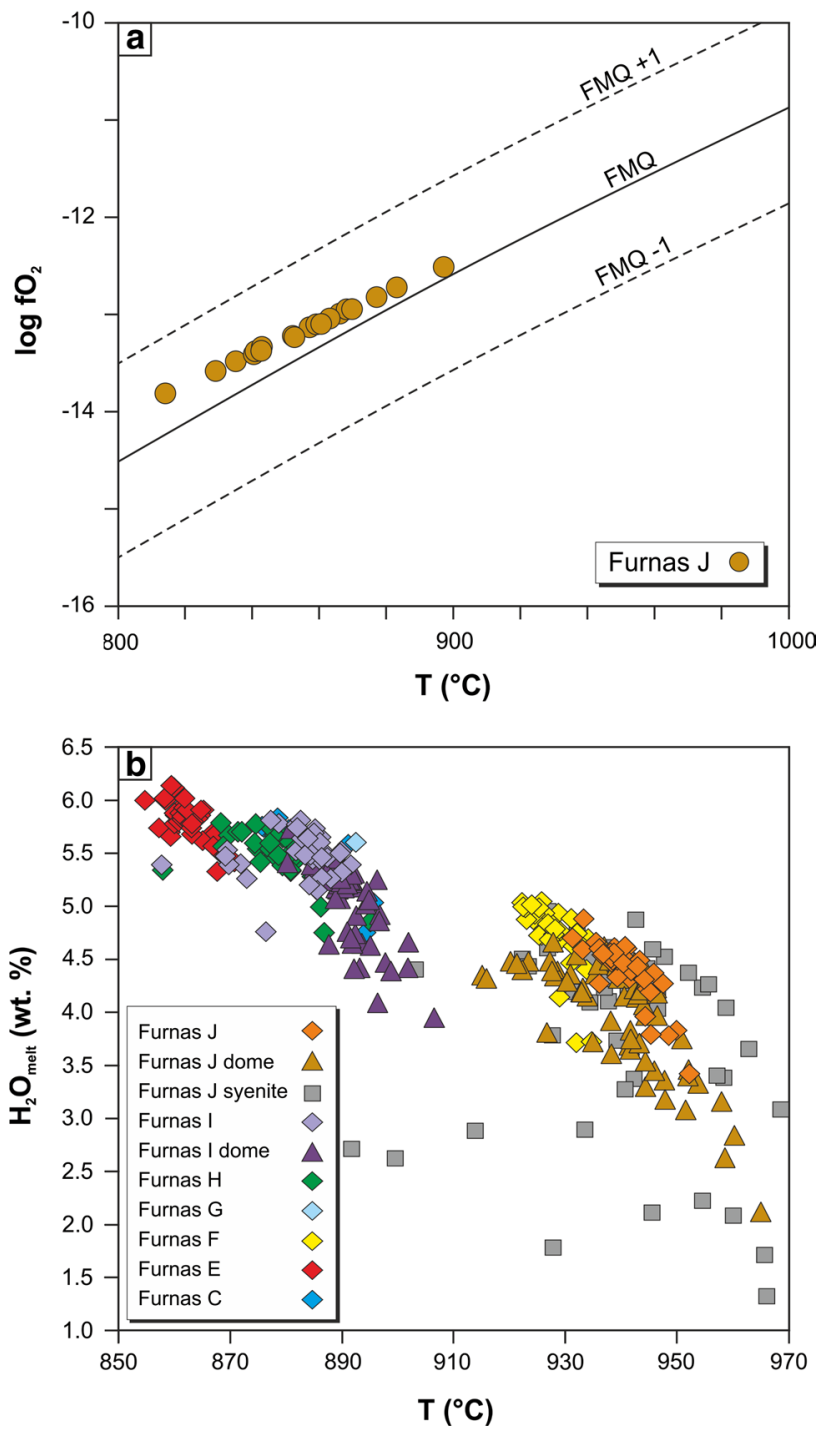

Fig. 6 Summarised results of thermobarometry and hygrometry, a $\mathrm{T}-\mathrm{fO}_{2}$ estimates for Furnas $\mathrm{J}$ derived from two-oxide models. FMQ buffer reaction curve calculated at $100 \mathrm{MPa}$, b $\mathrm{T}-\mathrm{H}_{2} \mathrm{O}_{\text {melt }}$ estimates produced via alkali feldspar-melt models

temperature and $\mathrm{H}_{2} \mathrm{O}_{\text {melt }}$ indicates that the UFG trachytes were $\mathrm{H}_{2} \mathrm{O}$ undersaturated prior to eruption. There is some evidence for variation in $\mathrm{H}_{2} \mathrm{O}_{\text {melt }}$ within individual eruptions. In the case of Furnas $\mathrm{J}$ and Furnas I, the late-stage lava domes both yield $\mathrm{H}_{2} \mathrm{O}_{\text {melt }}$ estimates that extend to somewhat lower values than the preceding pumice falls. This is most obvious for Furnas J, where the dome analyses return a range that extends as low as $2.4 \mathrm{wt} \%$, which is $>1 \mathrm{wt} \%$ lower than the lowest estimate for the Furnas $\mathbf{J}$ pumice fall. Syenite ejecta and their enclaves yield a range of estimates that are comparable to those of Furnas $\mathrm{J}$ and Furnas F, but show substantial scatter, ranging from 1.3 to $5.3 \mathrm{wt} \%$. 

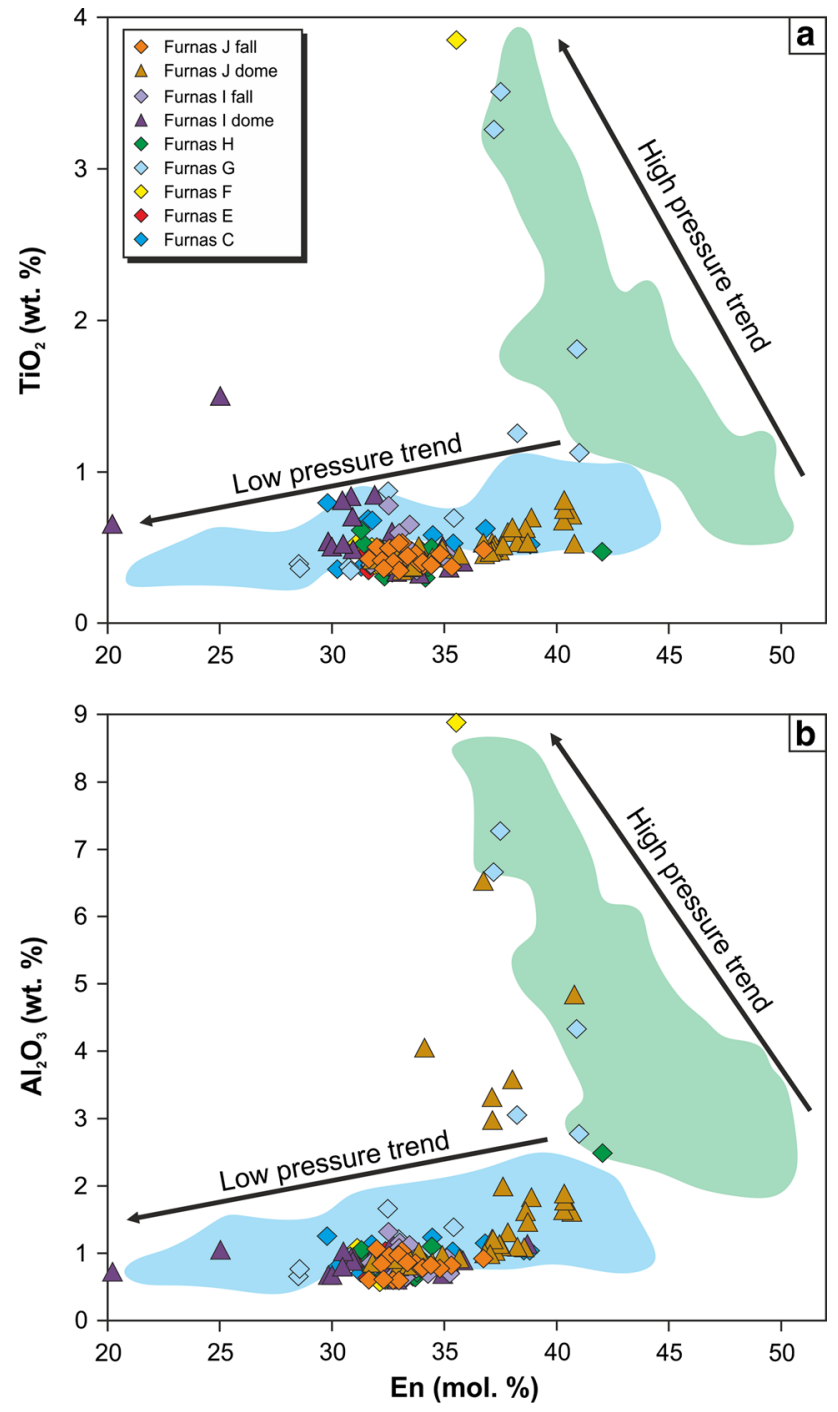

Fig. 7 Variations in $\mathrm{TiO}_{2}$ and $\mathrm{Al}_{2} \mathrm{O}_{3}$ content of clinopyroxene, plotted with reference to the high- and low-pressure trends identified at nearby Sete Cidades (Beier et al. 2006)

Equilibrium testing of clinopyroxene indicates that none of the reported UFG clinopyroxenes were in equilibrium with their host trachytes, precluding quantitative estimation of pre-eruptive conditions. Beier et al. (2006) noted a similar lack of crystal-melt equilibrium in trachytes from Sete Cidades. Application of hypothetical liquid compositions derived from Rhyolite-MELTs modelling indicates that the most suitable equilibrium liquid compositions are broadly trachyandesitic. Despite the lack of equilibrium, clinopyroxene chemistry may still allow qualitative insights into the magma system. Beier et al. (2006) observed two trends in clinopyroxene $\mathrm{Al}_{2} \mathrm{O}_{3}$ and $\mathrm{TiO}_{2}$ content at Sete Cidades: (1) high $\mathrm{Al}_{2} \mathrm{O}_{3}$ and $\mathrm{TiO}_{2}$ in the mafic rocks, and (2) low $\mathrm{Al}_{2} \mathrm{O}_{3}$ and $\mathrm{TiO}_{2}$ in the trachytes. These trends were attributed to high- and low-pressure crystallisation conditions, respectively. With the exception of a small amount of clinopyroxenes from a number of the UFG units, the UFG clinopyroxene population adheres to the low $\mathrm{Al}_{2} \mathrm{O}_{3}$ and $\mathrm{TiO}_{2}$ trend (Fig. 7). On this basis, the bulk of clinopyroxene crystallisation may be constrained to shallow crystal conditions. The small number of high-pressure clinopyroxenes may reflect an earlier high-pressure fractionation step, similar to that of Sete Cidades, which is poorly represented in the UFG trachytes.

\section{Constraints from $\mathrm{H}_{2} \mathrm{O}$ solubility}

Further constraints can be placed upon the minimum depth of the magma reservoir through the calculation of saturation pressures of the melt. To achieve this, the solubility models of Di Matteo et al. (2004) and Papale et al. (2006) were applied. The former applies a polynominal fit of experimental data to parameterise $\mathrm{H}_{2} \mathrm{O}$ solubility and yields an estimated minimum pressure of $122 \mathrm{MPa} \pm 15 \mathrm{MPa}$, assuming water saturation at $5.7 \mathrm{wt} \%$. The second model was applied using a representative anhydrous MET whole rock composition, and an input temperature of $908{ }^{\circ} \mathrm{C}$ (average alkali feldspar-melt equilibria-derived T of UFG), and produces a minimum pressure of $156 \mathrm{MPa}$.

\section{Petrogenesis of the UFG trachytes}

To investigate the roles of fractional crystallisation and partial melting of crustal rocks in the generation of the UFG trachytes, we employ Rayleigh fractionation and batch melting models, using sample 98SM33 of Elliott et al. (2007) as the parental magma, or a partially melted crustal gabbro, respectively (see Online Resource 4 for full details). Applied mineral-melt partition coefficients are given in Table 1 . Modelling of compatible trace elements such as $\mathrm{Sr}, \mathrm{Ba}$, and $\mathrm{Ni}$ indicate that batch melting models of gabbroic crust with variable mineral assemblages are unable to reproduce the low concentrations observed in the Furnas rocks (Fig. 8a, b, c). Instead, Rayleigh fractionation curves provide a better fit and suggest that the compositional variability of the UFG trachytes [least evolved trachytes (or LETs) to most evolved trachytes (or METs)] is largely controlled by 75-85\% fractionation of an alkali basaltic parent. Modelled fractionation curves for incompatible elements such as $\mathrm{Nb}$ and $\mathrm{Zr}$ indicate a similar range of fractionation values $(\sim 70-85 \%)$ (Fig. 8d). This is consistent with nearby Sete Cidades (Beier et al. 2006) and Fogo (e.g. Storey 1981; Widom et al. 1992), as well as other notable peralkaline centres such as Terceira (e.g. Mungall and Martin 1995) and Pantelleria (e.g. Neave et al. 2012), where fractional crystallisation plays a dominant role in magma evolution.

To further investigate the role of fractional crystallisation, major element mass balance models were applied 
Table 1 Partition coefficients used for trace element modelling

\begin{tabular}{|c|c|c|c|c|c|c|c|c|}
\hline & $\mathrm{Pl}$ & Cpx & $\mathrm{Ol}$ & Mt & $\mathrm{Bt}$ & Ap & Alk fsp & Ilm \\
\hline \multicolumn{9}{|c|}{ Step 1 RFC and batch melting } \\
\hline $\mathrm{Nb}$ & 0.0100 & 0.100 & 0.0100 & 0.900 & 0.0880 & & & \\
\hline $\mathrm{Zr}$ & 0.0100 & 0.120 & 0.0600 & 0.700 & 0.0170 & & & \\
\hline $\mathrm{Sr}$ & 10.0 & 0.700 & 0.0200 & & 0.700 & 1.20 & & \\
\hline $\mathrm{Ba}$ & 0.300 & 0.0400 & 0.0300 & & 3.68 & 0.0500 & & \\
\hline $\mathrm{Ni}$ & 0.270 & 2.50 & 34.0 & 48.0 & 23.9 & & & \\
\hline \multicolumn{9}{|c|}{ Step 2 RFC } \\
\hline $\mathrm{Nb}$ & & & & 0.180 & 0.740 & & 0.00400 & 11.6 \\
\hline $\mathrm{Zr}$ & & & & 0.250 & 0.100 & & 0.0300 & 0.0740 \\
\hline $\mathrm{Sr}$ & & & & 0.000 & 0.490 & 2.00 & 2.30 & 0.740 \\
\hline $\mathrm{Ba}$ & & & & 0.100 & 10.0 & 8.00 & 5.90 & \\
\hline $\mathrm{Ni}$ & & & & & 89.6 & 0.450 & 0.905 & 6.20 \\
\hline
\end{tabular}

All coefficients sourced from the GERM database (Nielsen 2006); see Online Resource 4 for details

$P l$ plagioclase, $C p x$ clinopyroxene, $O l$ olivine, $M t$ Ti-magnetite, Bt Biotite, Ap apatite, Alk $f s p$ alkali feldspar, Ilm ilmenite using the mineral compositions reported in Table 2. The results indicate that evolution from parental basalt to the LET (step 1) can be adequately explained $\left(\sum r^{2}=0.023\right)$ by $87.5 \%$ fractional crystallisation of a phase assemblage including clinopyroxene (45\%), plagioclase $(24 \%)$, Timagnetite $(12 \%)$, olivine (7\%), biotite $(10 \%)$, and apatite (2\%) (Table 3). The second evolutionary step (LET to MET) can be achieved by a further $38 \%$ fractional crystallisation of an assemblage dominated by alkali feldspar (94\%), with subsidiary Ti-magnetite (1\%), ilmenite (1\%), biotite $(3 \%)$, and apatite $(1 \%)\left(\sum r^{2}=0.018\right)$. Together, steps 1 and 2 indicate that the differentiation of parental basalt to the most evolved UFG trachyte can be accounted for by a total of $92 \%$ fractional crystallisation of an assemblage that is dominated by clinopyroxene and plagioclase during basalt to trachyte evolution, and alkali feldspar during continued evolution within the trachytes. The predicted late-stage prevalence of alkali feldspar fractionation is in agreement with the mineral assemblages of the trachytes, where alkali feldspar constitutes the dominant phenocryst phase. Predicted mafic-to-intermediate assemblages are broadly similar to available descriptions of mafic-to-intermediate rocks from across São Miguel (e.g. Moore 1991; Beier et al. 2006; Jeffery unpublished data).

The results of 150 Rhyolite-MELTs models indicate that a liquid of similar composition to the UFG trachytes (with respect to $\mathrm{MgO}, \mathrm{SiO}_{2}, \mathrm{Al}_{2} \mathrm{O}_{3}$, total alkalis, peralkalinity index, and $\mathrm{H}_{2} \mathrm{O}_{\text {melt }}$ ) can be produced via fractional crystallisation of a hydrous (1.5 wt \%) alkali basalt parent under low pressure $(150 \mathrm{MPa})$, at redox conditions close to the FMQ buffer reaction curve (Fig. 9). These conditions are consistent with those predicted via thermobarometrical models. This model predicts olivine as the liquidus phase $\left(1265{ }^{\circ} \mathrm{C}\right)$, followed by clinopyroxene and Ti-magnetite $\left(1115{ }^{\circ} \mathrm{C}\right)$, with clinopyroxene crystallisation ceasing at $905{ }^{\circ} \mathrm{C}$. This is followed by apatite $\left(1065^{\circ} \mathrm{C}\right)$ plagioclase feldspar $\left(985^{\circ} \mathrm{C}\right)$, biotite $\left(900{ }^{\circ} \mathrm{C}\right)$, and ilmenite $\left(795^{\circ} \mathrm{C}\right)$. The model reaches compositions similar to the METs of the UFG at $\sim 815{ }^{\circ} \mathrm{C}$, at which point the melt has undergone $\sim 86 \%$ fractionation of olivine $(\sim 10 \%)$, clinopyroxene $(\sim 42 \%)$, feldspar ( 22\%), Ti-magnetite $(\sim 10 \%)$, apatite $(\sim 1 \%)$, and biotite $(\sim 1 \%)$. Higher pressure (300 and $500 \mathrm{MPa}$ ) models fail to reach the silica and total alkali values exhibited by the UFG, peaking at approximately trachyandesitic compositions. Lower pressure (50 MPa) models underestimate liquid $\mathrm{Al}_{2} \mathrm{O}_{3}$ contents due to the earlier crystallisation of feldspar, leading to higher peralkalinity indices than observed in the UFG. Polybaric models also perform well, generating liquid compositions similar to the UFG when initial water content and redox conditions are set to $1.5 \mathrm{wt} \%$ and the FMQ buffer, respectively. However, these models yield silica and total alkali contents that are slightly lower than the UFG.

In addition to the described petrogenetic models, geochemical characteristics of the UFG highlight the role of fractional crystallisation. The observed depletion of $\mathrm{Ti}$ and $\mathrm{P}$ indicate the fractionation of $\mathrm{Fe}-\mathrm{Ti}$ oxides and apatite, respectively, whilst the extreme depletion of $\mathrm{Sr}$ and $\mathrm{Ba}$, and the large negative Eu anomaly that is typical of Furnas trachytes, reflects extensive fractionation of both plagioclase and alkali feldspars. Based upon the presented evidence, it is suggested that the trachytes of the UFG are primarily derived from between $\sim 70$ and $\sim 90 \%$ low-pressure fractional crystallisation of an alkali basaltic parental magma under redox conditions close to the FMQ buffer, although a minor contribution from crustal assimilation or partial melting of crustal lithologies cannot be ruled out entirely (e.g. Widom and Farquhar 2003; Snyder et al. 
Fig. 8 Results of trace element modelling. Calculated Rayleigh fractionation curves are labelled with RFC, and batch melting curves are labelled with BM. Ticked intervals represent $10 \%$ fractionation or partial melting. Analyses derived from ED-XRF are given with filled symbols, whilst those produced via WD-XRF or ICP-MS are shown with open symbols. Parental compositions are shown with a black circle

2004; Genske et al. 2013, 2014; Larrea et al. 2014). These elevated fractionation values are compatible with estimates from other peralkaline systems such as Pantelleria (White et al. 2009; Neave et al. 2012), Sete Cidades (Renzulli and Santi 2000; Beier et al. 2006), Fogo (Widom et al. 1992) and the East African Rift (Scaillet and Macdonald 2003; Rooney et al. 2012). The LETs are likely to have evolved via at least $70 \%$ fractionation from alkali basalt, through trachybasalt, basaltic trachyandesite, and trachyandesite, fractionating an assemblage that is initially dominated by clinopyroxene with subsidiary olivine and with feldspar becoming more significant at intermediate compositions. The METs are then produced by further fractional crystallisation of an assemblage dominated by alkali feldspar, with small amounts of biotite, Ti-magnetite, and apatite. The crystallisation of ilmenite is not predicted until $795^{\circ} \mathrm{C}$, which may suggest that the UFG magmas were predominantly stored at temperatures in excess of this value.

\section{Origin of syenitic cognate xenoliths}

Syenitic ejecta from the Furnas $\mathrm{J}$ eruption are considered to represent the final stages of crystallisation $\left(<800{ }^{\circ} \mathrm{C}\right)$, characterised by an assemblage that, whilst still dominated by alkali feldspar, also includes a range of clinopyroxene compositions (diopside, augite, hedenbergite, aegirine-augite, aegirine), sodic amphiboles, Ti-magnetite, and ilmenite. Amphiboles and clinopyroxenes of broadly similar composition were observed as interstitial phases in the Furnas I lava dome, suggesting that, like ilmenite, they only form at temperatures that are lower than those at which the UFG magmas were stored.

Based upon their geochemical and petrographical characteristics, the syenites are considered to represent in situ crystallisation at the thermal boundary zone of a magma reservoir, rather than cumulates from which significant melt volumes were extracted (cf. Widom et al. 1993). For example, evolution from LET to MET has been shown to be controlled by the fractionation of alkali feldspar, biotite, Ti-magnetite, and apatite. Neither Na-amphibole nor Naclinopyroxene is predicted in thermodynamic models, and both significantly decrease the fit of mass balance models when included, suggesting that the syenites cannot represent a cumulate from which the trachytes are derived.
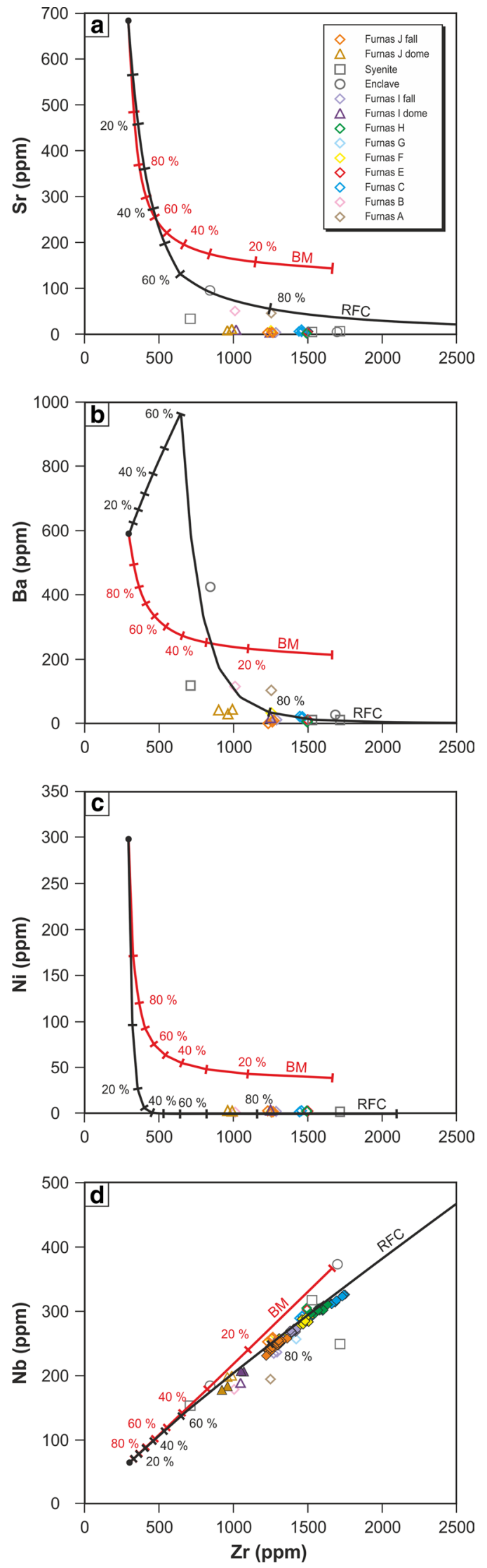
Table 2 Mineral compositions used for major element mass balance modelling

\begin{tabular}{|c|c|c|c|c|c|c|c|c|c|}
\hline Mineral & Pl & Alk fsp & $\mathrm{Ol}$ & Cpx & Mt-1 & Mt-2 & Ilm & $\mathrm{Bt}$ & Ap \\
\hline $\mathrm{SiO}_{2}$ & 54.71 & 65.15 & 40.44 & 52.26 & & & & 36.70 & \\
\hline $\mathrm{TiO}_{2}$ & & 0.09 & & 0.84 & 14.65 & 20.47 & 48.97 & 6.51 & \\
\hline $\mathrm{Al}_{2} \mathrm{O}_{3}$ & 29.28 & 19.00 & & 2.21 & 0.99 & 4.39 & 0.03 & 13.30 & \\
\hline $\mathrm{Fe}_{2} \mathrm{O}_{3}$ & & & & 3.37 & 40.01 & 26.61 & & 6.85 & \\
\hline $\mathrm{FeO}$ & 0.82 & 0.37 & 11.75 & 0.38 & 39.25 & 42.36 & 42.26 & 9.01 & \\
\hline $\mathrm{MnO}$ & & & 0.22 & 0.12 & 2.63 & 0.52 & 3.93 & 0.41 & \\
\hline $\mathrm{MgO}$ & & 0.01 & 47.32 & 16.71 & 1.77 & 4.99 & 3.31 & 13.91 & \\
\hline $\mathrm{CaO}$ & 10.30 & 0.54 & 0.28 & 22.37 & & & & & 55.70 \\
\hline $\mathrm{Na}_{2} \mathrm{O}$ & 4.83 & 6.87 & & 0.28 & & & & 0.97 & \\
\hline $\mathrm{K}_{2} \mathrm{O}$ & 0.43 & 6.69 & & & & & & 8.71 & \\
\hline $\mathrm{P}_{2} \mathrm{O}_{5}$ & & & & & & & & & 41.82 \\
\hline $\mathrm{H}_{2} \mathrm{O}$ & & & & & & & & & 0.59 \\
\hline
\end{tabular}

Mineral compositions for alkali feldspar (Alk fsp), Ti-magnetite (Mt-1), and ilmenite (Ilm) were taken from the data set of this study. Compositions for plagioclase ( $\mathrm{Pl})$, olivine $(\mathrm{Ol})$, clinopyroxene $(\mathrm{Cpx})$, Timagnetite (Mt-2) and biotite (Bt) were taken from Beier et al. (2006)
Similarly, the syenites and their enclaves show a wide range of trace element compositions that encompass those of the UFG, rendering many of the UFG eruptions less evolved than the syenites. If the syenite nodules did represent residual cumulates, they should be uniformly less evolved than the UFG trachytes. Furthermore, the syenites exhibit Eu anomalies that are comparable to, or greater than, those of the UFG trachytes. In the UFG rocks, a negative correlation is observed between $\mathrm{Eu} / \mathrm{Eu}^{*}$ and differentiation indices such as $\mathrm{Zr}$ and $\mathrm{Nb}$, suggesting that the accumulation of feldspar could only result in a less negative, or even positive, Eu anomaly. As such, it is suggested that the syenites represent near-complete, in situ crystallisation of unerupted trachytic magmas similar to those of the UFG. Their trace element variability is ultimately derived from the varying degrees of fractionation that also yield trace element diversity in the UFG trachytes, though hydrothermal alteration and the presence of accessory phases such as zircon also play a role.

\section{The role of magma mixing/mingling processes}

In addition to FC processes, a number of features of the UFG eruption products provide evidence for the role of replenishment and magma mingling between two variably evolved trachytes in the magma storage zone. For example, enclaves hosted in syenite ejecta display chilled margins, rounded, lobate forms, as well as large alkali feldspar phenocrysts which exhibit similar compositions to host syenite feldspar and pronounced disequilibrium textures at their rims, suggesting that they are xenocrysts derived from the host syenite. These features are all indicative of liquid emplacement, suggesting that the enclaves represent trachyte-syenite mingling in the highly crystalline mush zone at the margins of a magma reservoir.

Additionally, the presence of banded pumices in the uppermost pumice fall deposit of Furnas $\mathbf{J}$ (Lf) may provide direct evidence for mingling between two variably evolved trachytes during the later stages of the eruption, as has been described for the $\mathrm{C} 11$ explosive eruption $(\sim 1000$ ${ }^{14} \mathrm{C}$ y B.P.) of Caldeira volcano, Faial (Pimentel et al. 2015). Grey bands within the predominantly white pumices of Lf exhibit markedly lower vesicularity and thus may have been volatile poor (Cole et al. 1995). The same study presented evidence for variable viscosity of the two types based upon deformation characteristics, as well as geochemical analyses for each type, which, on the basis of $\mathrm{Zr}$ content, suggests that the dense grey pumice may be marginally less evolved. However, it should be noted that both analyses are $250-300 \mathrm{ppm}$ lower in $\mathrm{Zr}$ than the Lf analyses of this study and are instead comparable to the Furnas $\mathrm{J}$ lava dome analyses. This observation implies that there may be a relatively sharp geochemical transition from high $\mathrm{Zr}(\sim 1200 \mathrm{ppm})$ to low $\mathrm{Zr}(\sim 900 \mathrm{ppm})$ within the Lf unit. Additionally, the analyses of Cole et al. (1995) exhibit Ba contents an order of magnitude greater than typical UFG concentrations, which may indicate local resorption of alkali feldspar. A single analysis within the data set of this study reveals an anomalous enrichment of $\mathrm{Sr}$ (95 compared to $<10 \mathrm{ppm}$ ), which may reflect the same process.

\section{A conceptual model for the UFG magma plumbing system}

Based upon the range of pressure estimates derived from $\mathrm{H}_{2} \mathrm{O}$ solubility models and thermodynamic models 
Table 3 Results of major element mass balance modelling

\begin{tabular}{|c|c|c|c|c|c|}
\hline \multirow[t]{4}{*}{ Sample } & \multicolumn{3}{|c|}{ Liquid composition } & \multicolumn{2}{|c|}{ Fractionating phases } \\
\hline & \multicolumn{2}{|l|}{ Basalt } & \multirow{2}{*}{$\begin{array}{l}\text { LET } \\
\text { S022 }\end{array}$} & & \\
\hline & \multicolumn{2}{|c|}{ 98SM33 } & & & \\
\hline & Obs & Calc & Obs & & \\
\hline \multicolumn{6}{|c|}{ Step 1: Alkali basalt to LET } \\
\hline $\mathrm{SiO}_{2}$ & 46.22 & 46.17 & 63.20 & Cpx & 45.1 \\
\hline $\mathrm{TiO}_{2}$ & 3.41 & 3.29 & 0.57 & $\mathrm{Plg}$ & 23.9 \\
\hline $\mathrm{Al}_{2} \mathrm{O}_{3}$ & 10.89 & 10.93 & 17.83 & Mt & 12.3 \\
\hline $\mathrm{FeO}^{\mathrm{T}}$ & 11.44 & 11.48 & 3.34 & $\mathrm{Bt}$ & 10.2 \\
\hline $\mathrm{MnO}$ & 0.17 & 0.19 & 0.22 & $\mathrm{Ol}$ & 7.1 \\
\hline $\mathrm{MgO}$ & 11.53 & 11.53 & 0.38 & Ap & 1.6 \\
\hline $\mathrm{CaO}$ & 12.01 & 12.04 & 0.88 & & \\
\hline $\mathrm{Na}_{2} \mathrm{O}$ & 2.12 & 2.13 & 7.37 & & \\
\hline $\mathrm{K}_{2} \mathrm{O}$ & 1.59 & 1.65 & 6.03 & & \\
\hline $\mathrm{P}_{2} \mathrm{O}_{5}$ & 0.63 & 0.6 & 0.09 & & \\
\hline$\sum r^{2}$ & 0.023 & & & & \\
\hline $\mathrm{F}$ & 0.125 & & & & \\
\hline \multirow[t]{4}{*}{ Sample } & \multicolumn{3}{|c|}{ Liquid composition } & \multicolumn{2}{|c|}{ Fractionating phases } \\
\hline & \multicolumn{2}{|l|}{ LET } & \multicolumn{3}{|l|}{ MET } \\
\hline & \multicolumn{2}{|l|}{ S022 } & \\
\hline & Obs & Calc & Obs & & \\
\hline \multicolumn{6}{|c|}{ Step 2: LET to MET } \\
\hline $\mathrm{SiO}_{2}$ & 63.20 & 63.28 & 63.16 & Alk fsp & 94.1 \\
\hline $\mathrm{TiO}_{2}$ & 0.57 & 0.57 & 0.42 & $\mathrm{Bt}$ & 3.2 \\
\hline $\mathrm{Al}_{2} \mathrm{O}_{3}$ & 17.83 & 17.86 & 17.40 & Mt & 1.4 \\
\hline $\mathrm{FeO}^{\mathrm{T}}$ & 3.34 & 3.44 & 4.21 & Ap & 0.7 \\
\hline $\mathrm{MnO}$ & 0.22 & 0.22 & 0.30 & $\mathrm{Ilm}$ & 0.6 \\
\hline $\mathrm{MgO}$ & 0.38 & 0.4 & 0.32 & & \\
\hline $\mathrm{CaO}$ & 0.88 & 0.83 & 0.77 & & \\
\hline $\mathrm{Na}_{2} \mathrm{O}$ & 7.37 & 7.31 & 7.75 & & \\
\hline $\mathrm{K}_{2} \mathrm{O}$ & 6.03 & 5.94 & 5.49 & & \\
\hline $\mathrm{P}_{2} \mathrm{O}_{5}$ & 0.09 & 0.16 & 0.06 & & \\
\hline$\sum r^{2}$ & 0.018 & & & & \\
\hline F & 0.618 & & & & \\
\hline
\end{tabular}

Ap apatite, $P l g$ plagioclase, $A l k f s p$ alkali feldspar, $C p x$ clinopyroxene, $B t$ biotite, $O l$ olivine, $M t$ magnetite, Ilm ilmenite. LET least evolved trachyte, MET most evolved trachyte
( 122-156 MPa), the magma storage region of the UFG eruptions can be constrained to shallow crustal depths between 3 and $4 \mathrm{~km}$ (based upon an average crustal density of $2800 \mathrm{~kg} / \mathrm{m}^{3}$ ). This range compares favourably with previous estimates of magma storage beneath Furnas volcano (Machado 1972; Sigmundsson et al. 1995; Blanco et al. 1997; Camacho et al. 1997; Montesinos et al. 1999) and also the shallow magma reservoir of Sete Cidades (Beier et al. 2006). The results of thermodynamic modelling, as well as the predominantly low $\mathrm{Al}_{2} \mathrm{O}_{3}$ and $\mathrm{TiO}_{2}$ contents of clinopyroxene, suggest that much of the compositional range from basalt to MET is present at this depth (Fig. 10).

Based upon the decreasing melt densities predicted by Rhyolite-MELTs from basalt to trachyte ( 2580 to $\sim 2230 \mathrm{~kg} / \mathrm{m}^{3}$ ), it is suggested that the reservoir beneath Furnas is compositionally zoned, with dense mafic magmas at the base, and low-density, hydrous silicic magmas at the roof. Trachytic magmas at the roof may be further enriched in volatiles via upward migration of a vapour phase, further stabilising the density stratification. This configuration may account for the apparent Daly Gap observed at Furnas 


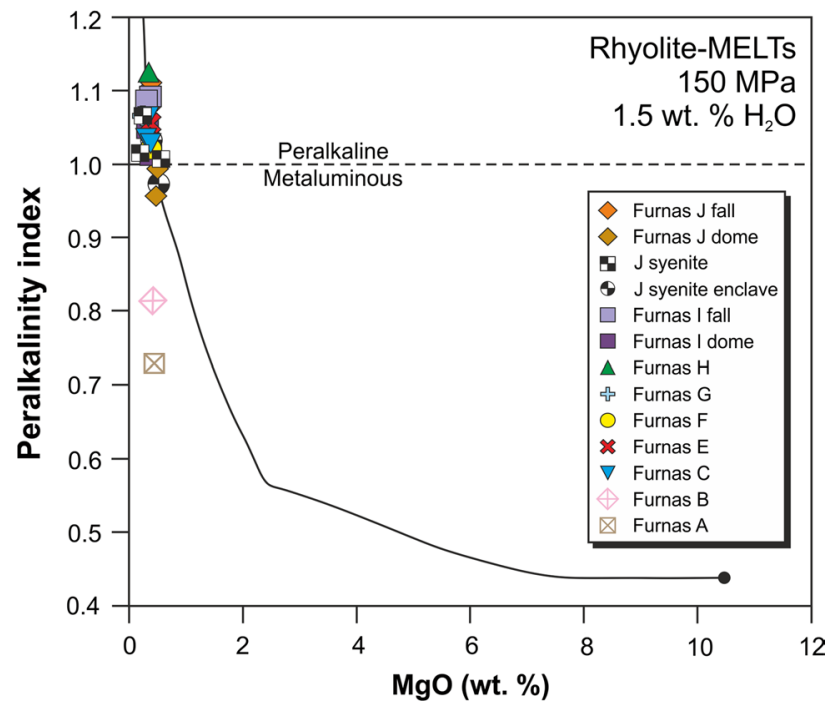

Fig. 9 Results of Rhyolite-MELTs fractional crystallisation modelling from an alkali basalt (black circle). Modelled curved produced at $150 \mathrm{MPa}$, with an initial water content of $1.5 \mathrm{wt} \%$
(Guest et al. 1999), as ascending mafic magmas may stall in an established shallow crustal magma reservoir and differentiate, ultimately contributing relatively small volumes of residual trachytic liquid to the silicic cap of the reservoir rather than erupting themselves (e.g. Mahood 1984; White et al. 2009; Neave et al. 2012). The likely presence of older, frozen reservoirs at this level is envisaged to further inhibit rapid magma ascent (e.g. Zanon and Pimentel 2015). In contrast, basalts that ascend outside the confines of the caldera and avoid the shallow system reached the surface and were erupted as the monogenetic cones and fissure eruptions that are typical of the volcano's flanks and the neighbouring Congro fissure volcanic system (Zanon 2015).

The generation of crystal poor silicic magmas, such as those of the UFG, is commonly accounted for through the application of models which involve the extraction of interstitial melt from large crystal mush bodies, citing processes such as compaction, microsettling, hindered settling, and gas-driven filter pressing (e.g. Sisson and Bacon 1999; Bachmann and Bergantz 2004; Hildreth 2004; Pistone

\section{W Congro fissure \\ E}
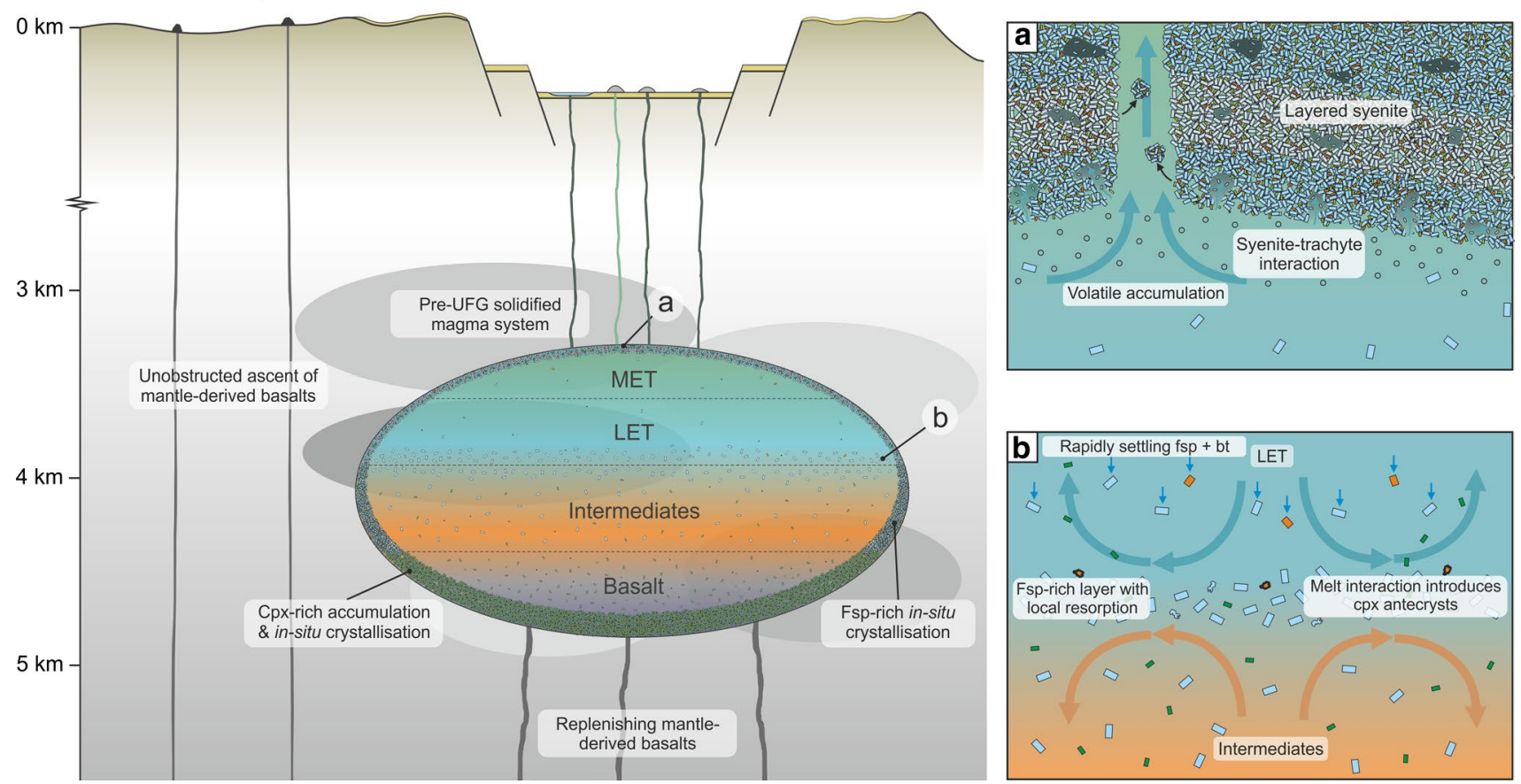

Fig. 10 A schematic model for the structure of the shallow plumbing system of Furnas volcano. A density-stratified magma reservoir with a trachytic cap is envisaged, at depths of approximately 3 to $4 \mathrm{~km}$, a syenite ejecta derived from an upper solidification front may be sampled during eruption. The solidified remnants of pre-UFG magma systems may provide an additional source of syenitic xenoliths, b interaction between individually convecting layers introduces an antecrystic clinopyroxene population to the cap, whilst rapidly settling feldspars form a Sr- and Ba-rich feldspar layer. Settling biotite phenocrysts originating from the upper most evolved trachytes (METs) are heavily resorbed by hotter underlying least evolved trachytes (LETs) and intermediates 
et al. 2015). Such models are attractive primarily because of the difficulties associated with two-phase flow in relatively cool, high viscosity $\left(\sim 10^{4.5} \mathrm{~Pa} \mathrm{~s}\right)$ melts (Scaillet et al. 1998). However, their application to peralkaline magmatic systems is complicated by the apparent absence of erupted crystal-rich melts (equivalent to the 'monotonous intermediates' associated with non-peralkaline systems, Macdonald 2012) and also by the tendency of peralkaline melts to have lower viscosities than their metaluminous and peraluminous equivalents (e.g. Giordano et al. 2006; Neave et al. 2012). The efficiency of two-phase flow in the UFG trachytes was investigated through the estimation of crystal free melt viscosities. Application of the model of Giordano et al. (2008) indicates that the trachytes, at a temperature of $908{ }^{\circ} \mathrm{C}$ and $\mathrm{H}_{2} \mathrm{O}_{\text {melt }}$ values from 2.4 to $5.7 \mathrm{wt} \%$, have viscosities ranging from $10^{2.7}$ to $10^{4.1} \mathrm{~Pa}$ s. The UFG trachytes therefore had pre-eruptive viscosities that were up to two orders of magnitude lower than typical silicic melts (Scaillet et al. 1998), which has implications for the dominant differentiation mechanism.

The efficiency of crystal settling was evaluated through the calculation of Stokes' settling velocities for alkali feldspar crystals (determined to be the most important crystallising phase during the later stages of magma evolution). This was supplemented with the hindered settling equation, which allows the determination of settling rates in polydispersed suspensions (Bachmann and Bergantz 2004):

$U_{\mathrm{hs}}=U_{\text {Stokes }} \times f(c)$

where $U_{\mathrm{hs}}$ is the hindered settling velocity, $U_{\text {Stokes }}$ is Stokes settling velocity, and $f(c)$ is a correction factor calculated as:

$$
f(c)=\frac{(1-c)^{2}}{\left(1+c^{1 / 3}\right)^{\left[\frac{5 c}{3(1-c)}\right]}}
$$

where $c$ is equal to the crystal fraction. Crystal sizes were set to $2 \mathrm{~mm}$, in accordance with petrographic observations. Results indicate that even for the highest viscosity estimate for the UFG, settling rates range from $0.51 \mathrm{~m} / \mathrm{a}^{-1}$ (hindered settling, $50 \%$ crystallinity) to $1.76 \mathrm{~m} / \mathrm{a}^{-1}$ (unhindered). Settling rates for the lowest viscosity trachytes reach values as high as $13.7 \mathrm{~m} / \mathrm{a}^{-1}$ (hindered settling, $50 \%$ crystallinity) and $47 \mathrm{~m} / \mathrm{a}^{-1}$ (unhindered). Assuming a volume of melt that is typical for the UFG eruptions $\left(0.1 \mathrm{~km}^{3}\right.$ DRE; Booth et al. 1978), and hypothetical magma reservoir aspect ratios of $1: 1: 1$ and $8: 1: 1$, alkali feldspar crystals would need to travel maximum distances of $\sim 470-235 \mathrm{~m}$ to be removed from the volume of erupted melt. Available radiocarbon ages (and associated errors) for the UFG indicate that repose times do not exceed 918 years, but are likely to be 190 years (Furnas I to J) or less (e.g. Furnas H to I, Guest et al. 1999). Over such short timescales (190 years), alkali feldspar crystals are capable of settling $\sim 100 \mathrm{~m}$ at the very least (highest viscosity), but are capable of settling far greater distances (up to $9600 \mathrm{~m}$ using the lowest calculated viscosity). It is therefore suggested that, unlike the rhyolitic systems to which crystal mush models may apply, crystal settling was a viable and efficient mechanism of differentiation in the UFG trachytes and may account not only for the nearly aphyric nature of the erupted trachytes, but also for the rapid rates of differentiation implied by the wide range in their degree of evolution.

Syenitic ejecta are considered to represent a solidification front at the volatile-rich cap of the reservoir, in which trachytic magmas near the margins of the reservoir solidify via in situ crystallisation. Phase assemblages including aegirine, Na-amphibole, and ilmenite are consistent with near-complete in situ crystallisation, whilst the presence of miarolitic cavities and pyrrhotite indicates the accumulation of volatile phases. Crystallisation temperatures estimated from Ti-magnetite-ilmenite pairs are at least $70{ }^{\circ} \mathrm{C}$ lower than estimates for the UFG pumice falls. High temperature estimates derived from alkali feldspar-melt equilibria $\left(892\right.$ to $969{ }^{\circ} \mathrm{C}$ ) are similar to those of Furnas $\mathrm{J}$ and likely reflect the relatively early formation of feldspar compared to later ilmenite, aegirine, and amphibole. Enclaves within the syenites are considered to represent interaction between the upper thermal boundary layer and the crystal poor liquids in the underlying crystal poor cupola. Small volumes of crystal poor trachytes are inferred to have infiltrated the overlying crystal mush and been quenched. In $\mathrm{Zr}-\mathrm{Nb}$ space, the majority of syenites and enclaves appear to lie along the same liquid line of descent as the UFG, implying a cogenetic association. Although $\mathrm{Zr}-\mathrm{Nb}$ relationships could be uncoupled by the crystallisation of Zr-bearing phases, the observed rarity of zircon, as well as it's restriction to pore spaces, imply that late-stage zircon was retained rather than fractionated. The substantial range in the degree of evolution observed in their whole rock chemistry $(\sim 700-1700 \mathrm{ppm} \mathrm{Zr})$ is likely to be a temporal effect, where the composition of a given syenite clast or enclave is related to the dominant melt composition in the roof zone of the reservoir, a feature which is shown to vary considerably. Additionally, it seems probable that this cupola would be zoned to some extent, exhibiting the same degree of composition variation as the UFG trachytes themselves. We therefore invoke an 'onion-skin' arrangement, similar to that of Widom et al. (1993), where random sampling of various layers of the roof zone yields a range of compositions. It should also be noted that a single syenite analysis appears to deviate from the UFG liquid line of descent in $\mathrm{Zr}-\mathrm{Nb}$ space, suggesting that it may represent a fragment of an alternative liquid line of descent. It thus cannot be ruled out that some syenitic ejecta may instead represent the 'fossilised' 
remnants of a pre-UFG magmatic system, entrained preor syn-eruptively within the erupted trachyte.

Attempts to employ clinopyroxene thermobarometry revealed that the clinopyroxenes are not in equilibrium with the host trachytes (see above), instead being equilibrated with a broadly trachyandesitic composition. This is consistent with thermodynamic models, which suggest that clinopyroxene becomes saturated in the melt at $1115{ }^{\circ} \mathrm{C}$ and crystallises until $905{ }^{\circ} \mathrm{C}$. Settling rates of clinopyroxene through the UFG trachytes are approximately three times faster than those of alkali feldspar, suggesting that the ubiquitous presence within the erupted trachytes requires a mechanism that is either continuous within the magma plumbing system, or occurs immediately prior to each eruption. Two possibilities for an origin are considered: (1) they are xenocrysts derived from the incorporation and assimilation of mafic wall rock material or (2) they are antecrystic relics derived from liquid-liquid interaction between the erupted trachytes and less evolved magmas. There is no petrographic evidence, such as crustal or cumulate xenoliths, to support the former hypothesis, and trace element models do not indicate partial melting as a significant petrogenetic process in the UFG. As such, the second hypothesis is favoured and, given the small but consistent presence of clinopyroxene throughout the UFG, implies the episodic interaction between trachytic and less evolved, clinopyroxene-bearing magmas, most likely at an interface between strata with contrasting densities.

\section{Development of zoned magma bodies}

Despite the apparent major element homogeneity and low eruptive volumes (generally $\sim 0.1 \mathrm{~km}^{3}$ DRE, Booth et al. 1978) of the intra-caldera UFG trachytes, trace element compositions indicate substantial variation. For example, both the Furnas $\mathbf{J}$ and Furnas I eruptions began with an initial pumice fall, followed by a late-stage lava dome; in both cases, the lava dome is, according to a variety of differentiation indices $\left(\mathrm{Zr}, \mathrm{Nb}, \mathrm{REE}, \mathrm{Eu} / \mathrm{Eu}^{*}\right)$, less evolved than its respective pumice fall. Such phenomena are generally attributed to the development of a zoned magma reservoir prior to eruption (e.g. Hildreth 1981) and suggest that the uppermost, eruptible region of the Furnas magma reservoir is able to develop rapidly and maintain compositional zonation over the timescales of the UFG. A variety of processes have been suggested to play a role in the development of zonation (e.g. Hildreth and Wilson 2007); however, due to the described low magma viscosities, it seems likely that zoning patterns in the UFG are the result of the efficient fractionation of alkali feldspar crystals, driving the melt towards MET compositions. The upwards increase in volatile content and associated decrease in viscosity may lead to a geochemical gradient via variably efficient fractionation (e.g. Furnas J, L1 to Lf).

The preservation of zonation in the UFG magmas until eruption indicates the absence of efficient convective cells able to rehomogenise the reservoir, which may be accounted for by a strong density gradient linked to the $\sim 4$ wt\% range in estimated melt water contents (cf. Hildreth and Wilson 2007). Alternatively, compositional zonation might be stabilised through the generation of multiple, individually convecting layers (e.g. Huppert and Sparks 1984), though the applicability of such a model in a low volume of magma $\left(<0.3 \mathrm{~km}^{3}\right)$ may be restricted. If the zoning patterns of the UFG magmas are considered to have been largely unaltered by conduit processes during ascent, then the potentially sharp compositional contact between the pumice falls and lava domes of Furnas I and J may provide evidence for individual strata, reflecting a compositional discontinuity that was present in the magma reservoir between hydrous MET, and underlying, volatile-poor LET. This would also indicate that either a deeper part of the reservoir was tapped than in the majority of previous eruptions or that the cap had not yet regenerated the comparatively large volumes of MET associated with older eruptions (e.g. Furnas C, $\sim 0.3 \mathrm{~km}^{3}$ DRE).

The zoning patterns observed in the Furnas $\mathrm{C}$ (and possibly F) deposits imply a more complex regime in which less evolved melts are capable of erupting prior to more evolved melts. The observed zoning patterns require more complex reservoir geometries, such as sequential eruption of multiple magma bodies, each acting as an independent evolving system (e.g. Cooper et al. 2012; Zanon et al. 2013; Pimentel et al. 2015). Alternatively, this complex zonation might originate from an irregular chamber geometry which allows lower regions to be tapped first.

\section{Temporal evolution of the UFG magma reservoir}

In addition to trace element zonation within individual eruptions, the UFG as a whole exhibits higher-order variations which provide insights into the temporal evolution of the previously described eruptible cap of the shallow crustal reservoir. The complex trace element profiles of the UFG (Fig. 11) are clearly inconsistent with the tapping of a single large magma batch, emplaced prior to the Furnas A eruption, and allowed to fractionate for $~ 5000$ years (maximum age of the UFG). Instead, the observed variability suggests a cyclical regime, in which a zoned, silicic cap forms at the top of the reservoir, and is partially erupted in one or more individual eruption events, before being re-established via continued fractionation and potentially mafic replenishment (Fig. 12). This is consistent with neighbouring Fogo volcano, where a similar regime of zoned cap formation and tapping over the same time 


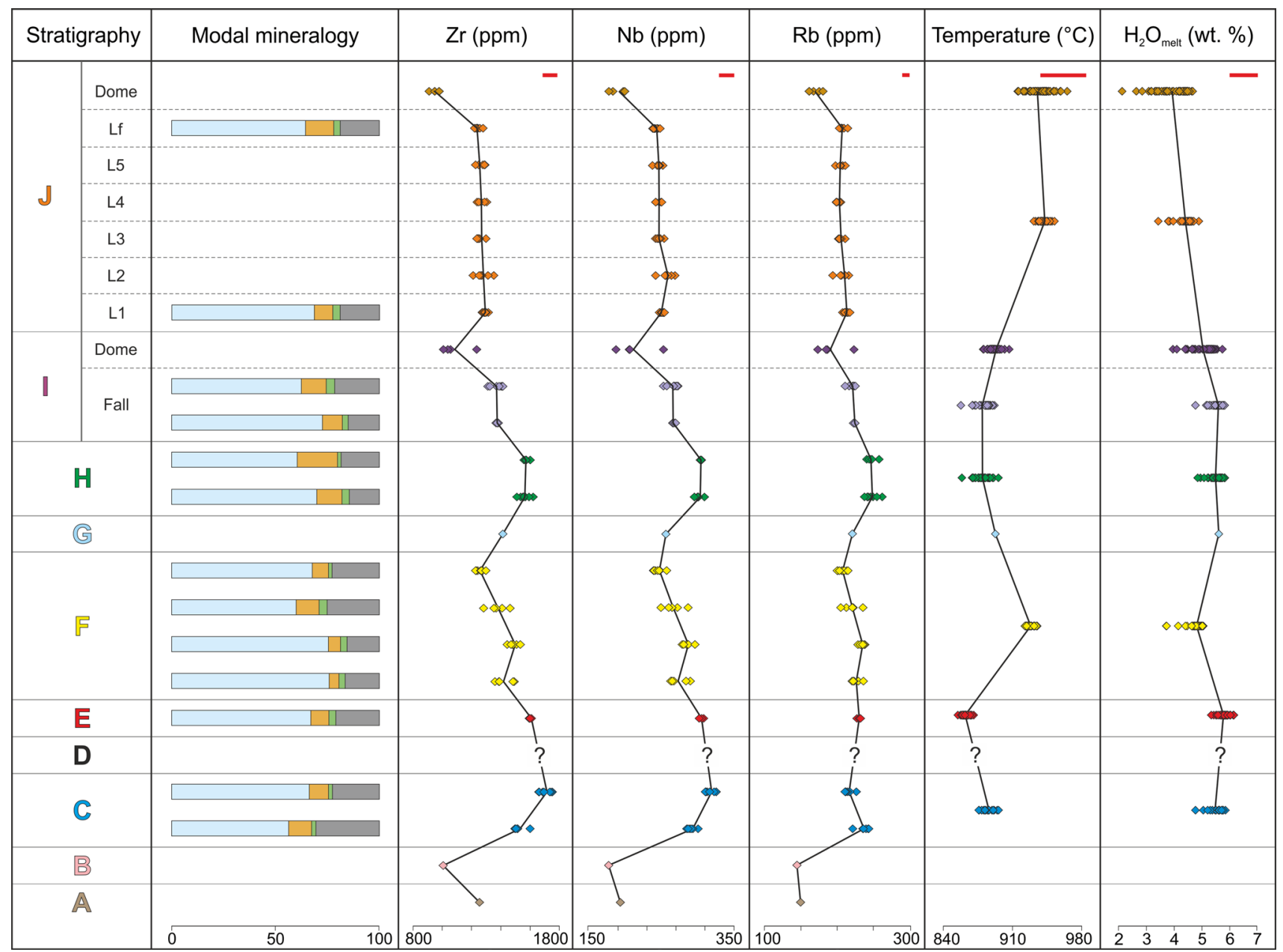

Fig. 11 Variations in trace element concentrations, temperature estimates, and $\mathrm{H}_{2} \mathrm{O}_{\text {melt }}$ estimates with stratigraphic height. Relevant errors are shown with red lines at the top of each column. Modal mineralogy: alkali feldspar $=$ blue, biotite $=$ orange , clinopyroxene $=$ green, $\mathrm{Fe}-\mathrm{Ti}$ oxides $=$ grey

eruption. Available radiocarbon ages suggest that the Furnas $\mathrm{B}$ to $\mathrm{C}$ repose period may have been up to 918 years.

The Furnas $\mathrm{C}, \mathrm{E}$, and $\mathrm{F}$ eruptions together indicate a trend of progressively less evolved trachytes, suggesting that they represent sequential, and probably relatively rapid, tapping of a single zoned magma body that formed following Furnas B. This indicates that, despite the relatively substantial volume of the Furnas $\mathrm{C}$ eruption compared to the other UFG eruptions $\left(0.3 \mathrm{~km}^{3} \mathrm{DRE}\right)$, the system was tapped a further three times prior to re-establishment, which may be linked to the repose time between eruptions, or the overall rate of trachyte replenishment in the cap. The repose periods between these eruptions are likely to have been comparatively short, limiting the effects of continued differentiation between eruptions. This period was followed by a period of fractionation, which culminated in the Furnas H eruption, and equated to 10-15\% fractionation. During this period, the reservoir was tapped 


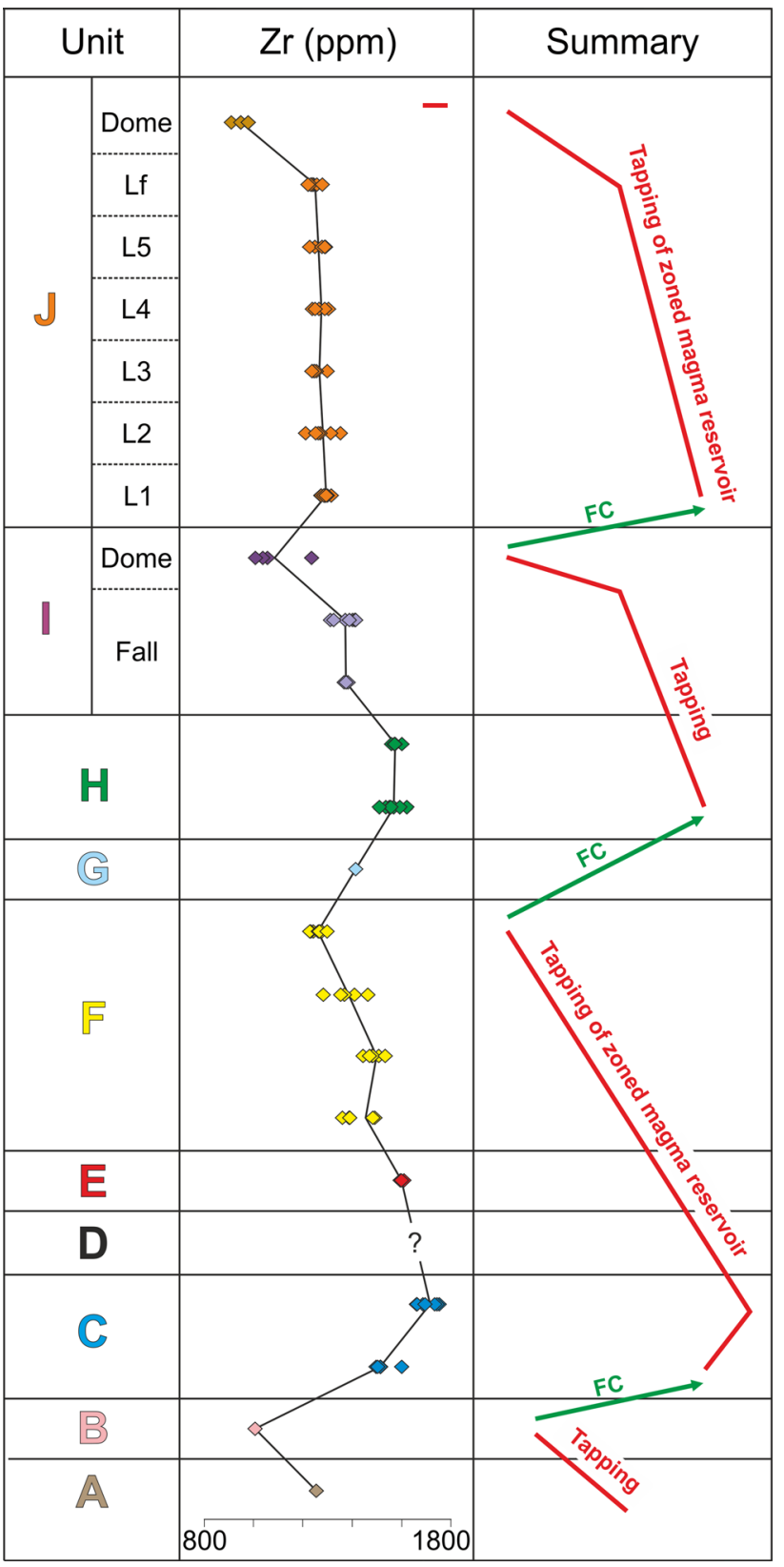

Fig. 12 A schematic model for cyclic replenishment and eruption phases throughout the UFG, based upon trace element compositions. See text for discussion. $F C$ fractional crystallisation

once by the Furnas $\mathrm{G}$ eruption, but this did not inhibit continued fractionation prior to Furnas $\mathrm{H}$.

The third zoned magma body is considered to have formed prior to Furnas $\mathrm{H}$ and been sequentially tapped by the Furnas $\mathrm{H}$ and I eruptions. This is consistent with the comparatively short repose time between Furnas H and I ( 20 years, Booth et al. 1978; Guest et al. 1999). Together, these eruptions define a trend of decreasing evolution that reverses the effect of fractional crystallisation by up to $\sim 35 \%$. This was followed by a repose period of $\sim 190$ years, during which the system evolved by up to $20 \%$ to produce the fourth zoned magma body, which was subsequently erupted in the Furnas J eruption. Based upon the similarity between the trace element profiles of the Furnas $\mathrm{I}$ and $\mathrm{J}$ eruptions, it is possible that the shallow magmatic system of Furnas has entered a new repose period whilst the eruptible cap reforms, though it should be noted that the current repose time of 385 years is approximately twice that of the I to J repose time ( 190 years).

\section{Implications for silicic volcanism on São Miguel}

The magma system of Furnas shares a number of features with neighbouring Fogo and Sete Cidades volcanoes. For example, a prominent, subcaldera, shallow crustal ( 3-4 km) magma reservoir has been identified at each volcano, in which mafic-to-intermediate magmas differentiate primarily via fractional crystallisation to form a cap of variably evolved trachyte (e.g. Storey 1981; Widom et al. 1992; Renzulli and Santi 2000; Beier et al. 2006). Evidence for magma mingling and mixing, such as phenocryst textures (Beier et al. 2006), hybrid magmas (Storey et al. 1989), and banded pumices (Widom et al. 1992; this study), is present at all three centres. However, felsic eruptive products are somewhat less dominant at Sete Cidades ( 75 vol\%; Moore 1991) than at Furnas and Fogo ( $\geq 90$ vol\%; Moore 1991), and the Daly Gap observed at both Furnas and Fogo is absent (Beier et al. 2006). One solution is that the upper, trachytic caps of the magma plumbing systems of both Furnas and Fogo are more developed, possibly due to periods of reduced basaltic input to the lower part of the systems (cf. Macdonald 2012). They would therefore form a more significant barrier against the ascent and eruption of basaltic magmas. In contrast, the magma plumbing system of Sete Cidades may be somewhat less developed and so unable to entirely prevent the ascent of basaltic magmas.

\section{Conclusions}

The compositional characteristics of the young $(<5 \mathrm{ka})$, intra-caldera trachytes of Furnas volcano can be adequately accounted for by extended fractional crystallisation from an alkali basalt parental magma at minimum depths of $\sim 3-4 \mathrm{~km}$. Fractionation is initially dominated by clinopyroxene, which is eventually replaced by alkali feldspar in the latter stages of differentiation. Despite their major element homogeneity, trace element compositions highlight the prominent role of continued fractional crystallisation within the trachytes, revealing up to $50 \%$ fractionation from the least evolved trachytes (LETs) to the most evolved trachytes (METs). This process is enhanced by the accumulation of water and the development of peralkalinity. 
The magma plumbing system is shown to comprise a single prominent zone in which alkali basalts evolve through to trachytic residual liquids. Due to density variations, this reservoir is envisaged to be stratified, with high-density mafic magmas at the base and relatively cool, hydrous trachytes forming an upper cap. Rare syenitic ejecta are considered to represent in situ, near-complete crystallisation of the trachytes in the roof zone of the reservoir, which is sampled randomly during eruption. Mingling and mixing within the trachytes is recorded by trachytic enclaves within the syenite ejecta and by the presence of banded pumices in Furnas J. Further evidence for mixing can be seen in the ubiquitous presence of small quantities of clinopyroxene antecrysts within all of the UFG eruptions, which are likely to be introduced to the trachytes during interaction with underlying, hotter, intermediate magmas. The presence of such a shallow reservoir may account for the Daly Gap at Furnas, as ascending mafic magmas are intercepted before reaching the surface, instead ponding in the lower reservoir and fractionating towards felsic compositions.

Despite the low volumes of the UFG eruptions $\left(\leq 0.3 \mathrm{~km}^{3} \mathrm{DRE}\right)$, variations in trace element concentrations within individual eruptions indicate zonation of the upper cap of the reservoir prior to eruption, with the most evolved melts typically being the first to erupt. Evidence exists for the presence of both chemical gradients and relatively sharp compositional stratification, which, in the case of the latter, are considered to represent sharp compositional discontinuities in the pre-eruptive magma reservoir, providing direct evidence for the presence of density stratification. Less distinct gradients likely result from the accumulation of volatiles, as well as the associated increase in crystal settling rates. Overall, trace element profiles of the UFG are not compatible with continued fractionation and tapping of a single magma batch and are instead indicative of a cyclic regime in which a compositionally stratified trachytic cap has formed and been sequentially erupted in up to three individual eruptions, before being re-established. This study suggests that there have been up to four such cycles of eruption and re-establishment within the UFG, with the 385-year repose time since the most recent eruption most likely representing a re-establishment phase.

Acknowledgments We gratefully acknowledge A. Tindle and A. Kronz for analytical support and access to electron microprobe facilities at The Open University, UK, and the University of Göttingen, Germany, respectively. We also acknowledge J. Watson and L. Thomas for assistance with XRF and ICP-MS analyses at The Open University, UK. We are grateful to B. Leze and K. Preece for their support in the production of additional XRF analyses at the University of East Anglia, UK. For assistance in the field, K. Ross is also acknowledged. We are also grateful to P. Greatbatch and D. Wilde for the production of thin sections and invaluable assistance in the preparation of melt inclusions for analysis. This manuscript was greatly improved by the insightful and constructive reviews of A. Klügel and C. Beier. We are grateful to J. Hoefs for editorial handling. This work was supported by the Faculty of Natural Sciences Research Office, Keele University, which provided use of facilities and financial support. A. Pimentel was financially supported by CIVISA/CVARG.

Open Access This article is distributed under the terms of the Creative Commons Attribution 4.0 International License (http://creativecommons.org/licenses/by/4.0/), which permits unrestricted use, distribution, and reproduction in any medium, provided you give appropriate credit to the original author(s) and the source, provide a link to the Creative Commons license, and indicate if changes were made.

\section{References}

Andersen DJ, Lindsley DH, Davidson PM (1993) QUILF: a Pascal program to assess equilibria among $\mathrm{Fe}-\mathrm{Mg}-\mathrm{Mn}-\mathrm{Ti}$ oxides, pyroxenes, olivine and quartz. Comput Geosci 19:1333-1350

Anderson AT (1968) Oxidation of the La Blanche Lake titaniferous magnetite deposit, Québec. J Geol 76:528-547

Avanzinelli R, Bindi L, Menchetti S, Conticelli S (2004) Crystallisation and genesis of peralkaline magmas from Pantelleria volcano, Italy: an integrated petrological and crystal-chemical study. Lithos 73:41-69

Bachmann O, Bergantz GW (2004) On the origin of crystal-poor rhyolites: extracted from batholithic crystal mushes. J Petrol 45:1565-1582

Bachmann O, Deering CD, Ruprecht JS, Huber C, Skopelitis A, Schnyder C (2012) Evolution of silicic magmas in the KosNisyros volcanic center, Greece: a petrological cycle associated with caldera collapse. Contrib Mineral Petrol 163:151-166

Bacon CR, Hirschmann MM (1988) Mg/Mn partitioning as a test for equilibrium between coexisting Fe-Ti oxides. Am Mineral 73:57-61

Barberi F, Ferrara G, Santacroce R, Treuil M, Varet J (1975) A transitional basalt-pantellerite sequence of fractional crystallisation, the Boina Centre (Afar Rift, Ethiopia). J Petrol 16:22-56

Beier C, Haase KM, Hansteen TH (2006) Magma evolution of the Sete Cidades volcano, São Miguel, Azores. J Petrol 47:1375-1411

Blanco I, García A, Torta JM (1997) Magnetic study of the Furnas caldera (Azores). Ann Geofis 40:341-359

Bohrson WA, Reid MR (1997) Genesis of silicic peralkaline volcanic rocks in an oceanic island setting by crustal melting and open-system processes: Socorro Island, Mexico. J Petrol 38:1137-1166

Booth B, Croasdale R, Walker GPL (1978) A quantitative study of five thousand years of volcanism on São Miguel, Azores. Philos Trans R Soc A 288:271-319

Camacho AG, Montesinos FG, Vieira R (1997) A three-dimensional gravity inversion applied to São Miguel Island (Azores). J Geophys Res 102:7717-7730

Carmichael ISE (1967) The iron-titanium oxides of salic volcanic rocks and their associated ferromagnesian silicates. Contrib Mineral Petrol 14:36-64

Chester DK, Dibben JL, Duncan AM (2002) Volcanic hazard assessment in western Europe. J Volcanol Geotherm Res 115:411-435

Civetta L, D'antonio M, Orsi G, Tilton GR (1998) The geochemistry of volcanic rocks from Pantelleria Island, Sicily Channel: petrogenesis and characteristics of the mantle source region. J Petrol 39:1453-1491

Cole PD, Queiroz G, Wallenstein N, Gaspar JL, Duncan AM, Guest JE (1995) An historic subplinian/phreatomagmatic eruption: the 1630 AD eruption of Furnas volcano, São Miguel, Azores. J Volcanol Geotherm Res 69:117-135 
Cole PD, Guest JE, Queiroz G, Wallenstein N, Pacheco JM, Gaspar JL, Ferreira T, Duncan AM (1999) Styles of volcanism and volcanic hazards on Furnas volcano, São Miguel, Azores. J Volcanol Geotherm Res 92:39-53

Cooper GF, Wilson CJ, Millet M, Baker JA, Smith EG (2012) Systematic tapping of independent magma chambers during the $1 \mathrm{Ma}$ Kidnappers super eruption. Earth Planet Sci Lett 313:23-33

Di Matteo V, Carroll MR, Behrens H, Vetere F, Brooker RA (2004) Water solubility in trachytic melts. Chem Geol 213:187-196

Duncan AM, Queiroz G, Guest JE, Cole PD, Wallenstein N, Pacheco JM (1999) The Povoação Ignimbrite, Furnas volcano, São Miguel, Azores. J Volcanol Geotherm Res 92:55-65

Elliott T, Blichert-Toft J, Heumann A, Koetsier G, Forjaz V (2007) The origin of enriched mantle beneath São Miguel, Azores. Geochim Cosmochim Acta 71:219-240

Freire Luis J, Miranda JM, Galdeano A, Patriat P, Rossignol JC, Mendes Victor LA (1994) The Azores triple junction evolution since $10 \mathrm{Ma}$ from an aeromagnetic survey of the Mid-Atlantic Ridge. Earth Planet Sci Lett 125:439-459

Gardner JE, Rutherford M, Carey S, Sigurdsson H (1995) Experimental constraints on pre-eruptive water contents and changing magma storage prior to explosive eruptions of Mount St Helens volcano. Bull Volc 57:1-17

Genske FS, Beier C, Haase KM, Turner SP, Krumm S, Brandl PA (2013) Oxygen isotopes in the Azores islands: crustal assimilation recorded in olivine. Geology 41:491-494

Genske FS, Turner SP, Beier C, Chu MF, Tonarini S, Pearson NJ, Haase KM (2014) Lithium and boron isotope systematics in lavas from the Azores islands reveal crustal assimilation. Chem Geol 373:27-36

Gente P, Dyment J, Maia M, Goslin J (2003) Interaction between the Mid-Atlantic Ridge and the Azores hot spot during the last 85 Myr: emplacement and rifting of the hotspot derived plateaus. Geochem Geophys Geosyst 4:8514. doi:10.1029/2003GC000527

Giordano D, Mangiacapra A, Potuzak M, Russell JK, Romano C, Dingwell DB, Di Muro A (2006) An expanded non-Arrhenian model for silicate melt viscosity: a treatment for metaluminous, peraluminous and peralkaline liquids. Chem Geol 229:42-56

Giordano D, Russell JK, Dingwell DB (2008) Viscosity of magmatic liquids: a model. Earth Planet Sci Lett 271:123-134

Guest JE, Gaspar JL, Cole PD, Queiroz G, Duncan AM, Wallenstein N, Ferreira T, Pacheco JM (1999) Volcanic geology of Furnas volcano, São Miguel, Azores. J Volcanol Geotherm Res 92:1-29

Guest JE, Pacheco JM, Cole PD, Duncan AM, Wallenstein N, Queiroz G, Gaspar JL, Ferreira T (2015) The volcanic history of Furnas Volcano, São Miguel, Azores. In: Gaspar JL, Guest JE, Duncan AM, Barriga FJAS, Chester DK (eds) 2015, Volcanic geology of São Miguel island (Azores archipelago). Geol Soc Lond Mem 44:125-134

Harris C (1983) The petrology of lavas and associated plutonic inclusions of Ascension Island. J Petrol 24:424-470

Hildreth W (1981) Gradients in silicic magma chambers: implications for lithospheric magmatism. J Geophys Res 86:10153-10192

Hildreth W (2004) Volcanological perspectives on Long Valley, Mammoth Mountain, and Mono Craters: several contiguous but discrete systems. J Volcanol Geotherm Res 136:169-198

Hildreth W, Wilson CJN (2007) Compositional zoning of the Bishop Tuff. J Petrol 48:951-999

Huppert HE, Sparks RSJ (1984) Double diffusive convection due to crystallisation in magmas. Annu Rev Earth Planet Sci 12:11-37

Jeffery AJ (2016) Petrogenesis and contrasting eruption styles of peralkaline silicic magmas from Terceira and São Miguel, Azores. Unpublished PhD thesis, Keele University, UK

Jeffery AJ, Gertisser R, Jackson RA, O’Driscoll B, Kronz A (2016) On the compositional variability of dalyite, $\mathrm{K}_{2} \mathrm{ZrSi}_{6} \mathrm{O}_{15}$ : a new occurrence from Terceira, Azores. Mineral Mag. doi:10.1180/ minmag.2016.080.018
Jones G, Chester DK, Shooshtariam F (1999) Statistical analysis of the frequency of eruptions at Furnas Volcano, São Miguel, Azores. J Volcanol Geotherm Res 92:31-38

Kaula WM (1970) Earth's gravity field: relation to global tectonics. Science 169:982-985

Krause DC, Watkins ND (1970) North Atlantic crustal genesis in the vicinity of the Azores. Geophys J R Astro Soc 19:261-283

Larrea P, Galé C, Ubide T, Widom E, Lago M, França Z (2014) Magmatic evolution of Graciosa (Azores, Portugal). J Petrol 55:2125-2154

Le Bas MJ, Le Maitre RW, Streckeisen A, Zanettin B (1986) A chemical classification of volcanic rocks based on the Total Alkali-Silica diagram. J Petrol 27:745-750

Leake BE, Woolley AR, Arps CES, Birch WD, Gilbert MC, Grice JD, Hawthorne FC, Kato A, Kisch HJ, Krivovichev VG, Linthout K, Laird J, Mandarino JA, Maresch WV, Nickel EH, Rock NMS, Schumacher JC, Smith DC, Stephenson NCN, Ungaretti L, Whittaker EJW, Youzhi G (1997) Nomenclature of amphiboles: report of the subcommittee on amphiboles of the international mineralogical association, commission on new minerals and mineral names. Can Mineral 35:219-246

Lepage LD (2003) ILMAT: an excel worksheet for ilmenite-magnetite geothermometry and geobarometry. Comput Geosci 29:673-678

Lindsley DH, Spencer KJ (1982) Fe-Ti oxide geothermometry: reducing analyses of coexisting Ti-magnetite (Mt) and ilmenite (Ilm). EOS Trans Am Geophys Union 63:471

Luis JF, Miranda JM (2008) Reevaluation of magnetic chrons in the North Atlantic between $35^{\circ} \mathrm{N}$ and $47^{\circ} \mathrm{N}$ : implications for the formation of the Azores Triple Junction and associated plateau. J Geophys Res 113:B10105

Macdonald R (2012) Evolution of peralkaline silicic complexes: lessons from the extrusive rocks. Lithos 152:11-22

Macdonald R, Sumita M, Schmincke HU, Bagiński B, White JC, Ilnicki SS (2015) Peralkaline felsic magmatism at the Nemrut volcano, Turkey: impact of volcanism on the evolution of Lake Van (Anatolia) IV. Contrib Mineral Petrol 169:34

Machado F (1972) Acid volcanoes of San Miguel, Azores. Bull Volc 36:319-327

Mahood GA (1984) Pyroclastic rocks and calderas associated with strongly peralkaline magmatism. J Geophys Res 89:8540-8552

Markl G, Marks MAW, Frost BR (2010) On the controls of oxygen fugacity in the generation and crystallisation of peralkaline melts. J Petrol 51:1831-1847

Marks MAW, Schilling J, Coulson IM, Wenzel T, Markl G (2008) The alkaline-peralkaline Tamazeght complex, High Atlas Mountains, Morocco: mineral chemistry and petrological constraints for derivation from a compositionally heterogeneous mantle source. J Petrol 49:1097-1131

Marks MAW, Hettmann K, Schilling J, Frost BR, Markl G (2011) The mineralogical diversity of alkaline igneous rocks: critical factors for the transition from miaskitic to agpaitic phase assemblages. $\mathbf{J}$ Petrol 52:439-455

Mollo S, Masotta M, Forni F, Bachmann O, De Astis G, Moore G, Scarlato P (2015) A K-feldspar-liquid hygrometer specific to alkaline differentiated magmas. Chem Geol 392:1-8

Montesinos FG, Camacho AG, Vieira R (1999) Analysis of gravimetric anomalies in Furnas caldera (São Miguel, Azores). J Volcanol Geotherm Res 92:67-81

Moore RB (1990) Volcanic geology and eruption frequency, São Miguel, Azores. Bull Volc 52:602-614

Moore RB (1991) Geology of three Late Quaternary stratovolcanoes on São Miguel, Azores. U.S. Geol Surv Bull 1900:1-46

Moore RB, Rubin M (1991) Radiocarbon dates for lava flows and pyroclastic deposits on São Miguel, Azores. Radiocarbon 33:151-164

Morimoto N, Fabries J, Ferguson AK, Ginzburg IV, Ross M, Seifert FA, Zussman J, Aoki K, Gottardi G (1988) Nomenclature of pyroxenes. Mineral Mag 52:535-550 
Mungall JE, Martin RF (1995) Petrogenesis of basalt-comendite and basalt pantellerite suites, Terceira, Azores, and some implications for the origin of oceanic-island rhyolites. Contrib Mineral Petrol 119:43-55

Neave DA, Fabbro G, Herd RA, Petrone CM, Edmonds M (2012) Melting, differentiation and degassing at the Pantelleria volcano, Italy. J Petrol 53:637-663

Nielsen R (2006) Geochemical earth reference model (GERM) partition coefficient $(\mathrm{Kd})$ database. www.earthref.org/KDD/

Papale P, Moretti R, Barbato D (2006) The compositional dependence of the saturation surface of $\mathrm{H}_{2} \mathrm{O}+\mathrm{CO}_{2}$ fluids in silicate melts. Chem Geol 229:78-95

Peccerillo A, Donati C, Santo AP, Orlando A, Yirgu G, Ayalew D (2007) Petrogenesis of silicic peralkaline rocks in the Ethiopian rift: geochemical evidence and volcanological implications. J Afr Earth Sci 48:161-173

Pensa A, Giordano G, Cas RAF, Porreca M (2015) Thermal state and implications for eruptive styles of the intra-Plinian and climactic ignimbrites of the $4.6 \mathrm{ka}$ Fogo A eruption sequence, São Miguel, Azores. Bull Volcanol 77:99

Pimentel A, Pacheco J, Self S (2015) The 1000-years BP explosive eruption of Caldeira Volcano (Faial, Azores): the first stage of incremental caldera formation. Bull Volc 77:42

Pistone M, Arzilli F, Dobson KJ, Cordonnier B, Reusser E, Ulmer P, Marone F, Whittington AG, Mancini L, Fife JL, Blundy JD (2015) Gas-driven filter pressing in magmas: insights into in situ melt segregation from crystal mushes. Geology 43:699-702

Putirka KD (2008) Thermometers and barometers for volcanic systems. Rev Mineral Geochem 69:61-120

Renzulli A, Santi P (2000) Two-stage fractionation history of the alkali basalt-trachyte series of Sete Cidades volcano (São Miguel island, Azores). Eur J Mineral 12:469-494

Ridley WI, Watkins ND, MacFarlane DJ (1974) Chapter 12: The Oceanic Islands: Azores. In: Nairn AEM, Stehli FG (eds) The ocean basins and margins, vol 2: The North Atlantic. Plenum Press, London, pp 445-484

Ridolfi F, Renzulli A, Santi P, Upton BGJ (2003) Evolutionary stages of crystallization of weakly peralkaline syenites: evidence from ejecta in the plinian deposits of Agua de Pau volcano (São Miguel, Azores Islands). Mineral Mag 67:749-767

Rooney TO, Hart WK, Hall CM, Ayalew D, Ghiorso MS, Hidalgo P, Yirgu G (2012) Peralkaline magma evolution and the tephra record in the Ethiopian Rift. Contrib Mineral Petrol 164:407-426

Scaillet B, Macdonald R (2001) Phase relations of peralkaline silicic magmas and petrogenetic implications. J Petrol 42:825-845

Scaillet B, Macdonald R (2003) Experimental constraints on the relationships between peralkaline rhyolites of the Kenya Rift Valley. J Petrol 44:1867-1894

Scaillet B, Holtz F, Pichavant M (1998) Phase equilibrium constraints on the viscosity of silicic magmas 1 . Volcanic-plutonic comparison. J Geophys Res 103:27257-27266

Schmincke HU, Weibel M (1972) Chemical study of rocks from Madeira, Porto Santo and São Miguel, Terceira (Azores). Neues Jahrb Mineral Abh 117:253-281

Searle R (1980) Tectonic pattern of the Azores spreading centre and triple junction. Earth Planet Sci Lett 51:415-434

Self S, Gunn BM (1976) Petrology, volume and age relations of alkaline and saturated peralkaline volcanics from Terceira, Azores. Contrib Mineral Petrol 54:293-313

Sibrant ALR, Hildenbrand A, Margues FO, Wiess B, Boulesteix T, Hübscher C, Lüdmann T, Costa ACG, Catalão JC (2015) Morpho-structural evolution of a volcanic island developed inside an active oceanic rift: S. Miguel Island (Terceira Rift, Azores). J Volcanol Geotherm Res 301:90-106

Sigmundsson F, Tryggvason E, Alves MM, Alves JL, Pálsson K, Ólafsson H (1995) Slow inflation of the Furnas volcano, São Miguel,
Azores, suggested from initial levelling and global positioning system measurements. Geophys Res Lett 22:1681-1684

Sisson TW, Bacon CR (1999) Gas-driven filter pressing in magmas. Geology 27:613-616

Snyder DC, Widom E, Pietruszka AJ, Carlson RW (2004) The role of open-system processes in the development of silicic magma chambers: a chemical and isotopic investigation of the Fogo A trachyte deposit, São Miguel, Azores. J Petrol 45:723-738

Storey M (1981) Trachytic pyroclasts from Agua de Pau volcano, São Miguel, Azores: evolution of a magma body over 4000 years. Contrib Mineral Petrol 78:423-432

Storey M, Wolff JA, Norry MJ, Marriner GF (1989) Origin of hybrid lavas from Agua de Pau volcano, São Miguel, Azores. In: Saunders AD, Norry MJ (eds) Magmatism in the ocean basins. Blackwell, London, pp 161-180

Stormer JC Jr (1983) The effects of recalculation on estimates of temperature and oxygen fugacity from analyses of multi-component iron-titanium oxides. Am Mineral 68:586-594

Sun S, McDonough WF (1989) Chemical and isotopic systematics of ocean basins: implications for mantle composition and processes. In: Saunders AD, Norry MJ (eds) Magmatism in the ocean basins. Geol Soc Lond Spec Publ 42:313-346

Trua T, Deniel C, Mazzuoli R (1999) Crustal control in the genesis of Plio-Quaternary bimodal magmatism of the Main Ethiopian Rift (MER): geochemical and isotopic ( $\mathrm{Sr}, \mathrm{Nd}, \mathrm{Pb}$ ) evidence. Chem Geol 155:201-231

Venezky DY, Rutherford MJ (1999) Petrology and Fe-Ti oxide reequilibration of the 1991 Mount Unzen mixed magma. J Volcanol Geotherm Res 89:213-230

Vogt PR, Jung WY (2004) The Terceira Rift as hyper-slow, hotspotdominated oblique speeding axis: a comparison with other slowspreading plate boundaries. Earth Planet Sci Lett 218:77-90

Walker GPL, Croasdale R (1971) Two plinian-type eruptions in the Azores. J Geol Soc London 127:17-55

Wallenstein N (1999) Estudo da história recente e do comportamento eruptivo do vulcão do Fogo (S. Miguel, Açores). Avaliação preliminar do hazard. Unpublished PhD thesis, Departamento de Geociências Universidades dos Açores, São Miguel Island (Portugal)

White JC, Parker DF, Ren M (2009) The origin of trachyte and pantellerite from Pantelleria, Italy: insights from major element, trace element, and thermodynamic modelling. J Volcanol Geotherm Res 179:33-55

Widom E, Farquhar J (2003) Oxygen isotope signatures in olivines from São Miguel (Azores) basalts: implications for crustal and mantle processes. Chem Geol 193:237-255

Widom E, Schmincke HU, Gill JB (1992) Processes and timescales in the evolution of a chemically zoned trachyte: Fogo A, São Miguel, Azores. Contrib Mineral Petrol 111:311-328

Widom E, Gill JB, Schmincke HU (1993) Syenite nodules as a longterm record of magmatic activity in Agua de Pau Volcano, São Miguel, Azores. J Petrol 34:929-953

Wolff JA (1987) Crystallisation of nepheline syenite in a subvolcanic magma system: Tenerife, Canary Islands. Lithos 20:207-223

Zanon V (2015) Conditions for mafic magma storage beneath fissure zones at oceanic islands. The case of São Miguel island (Azores archipelago). In: Caricchi L, Blundy JD (eds) Chemical, physical and temporal evolution of magmatic systems. Geol Soc Lond Spec Publ 422. doi:10.1144/SP422.4

Zanon V, Pimentel A (2015) Spatio-temporal constraints on magma storage and ascent conditions in a transtensional tectonic setting: the case of the Terceira Island (Azores). Am Mineral 100:795-805

Zanon V, Kueppers U, Pacheco JM, Cruz I (2013) Volcanism from fissure zones and the Caldeira central volcano of Faial Island, Azores archipelago: geochemical processes in multiple feeding systems. Geol Mag 150:536-555 